\title{
القانون الواجب التطبيق على إثبات النسب
}

\author{
shel \\ دار رشا علي الدين \\ أستاذ القانون الدولي الخاص المساعد \\ كليتالحقوق_جامعت المنصورة
}


د ارشا على الدين أحمد

العدد 09 ( ابريل 17. (17) 


\section{هقدمة}

الأولاد هم ثمرة الحياة الزوجية والغاية منها، وهم المستقبل لأي أمة، ولهذا كان

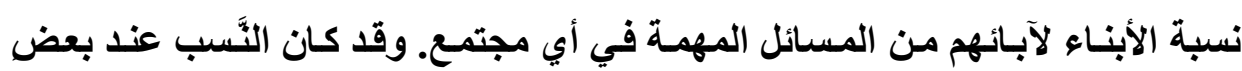

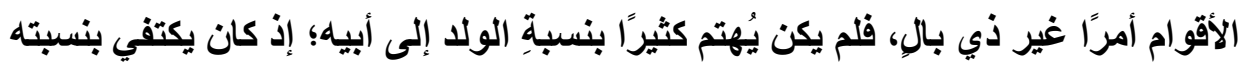

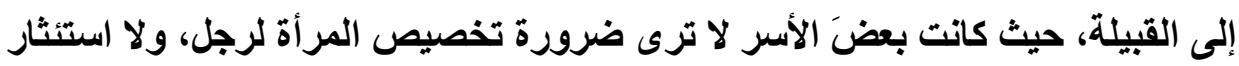

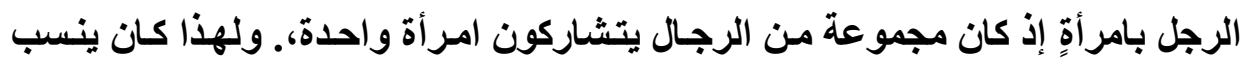

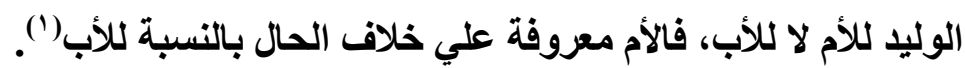
ومـع تطور الحياة الإنسانية، وتهذب السلوك البشري، ظهرت فكرة الزواج، واستثنار رجل بامرأة واحدة. وصار الحديث حول نسبة الأبناء للأب، بالإضافة لنسبته

وجاءت شريعتنا الإسلامية الغراء لتعتبر النسب من الحقوق المهمة التي أثبتتها

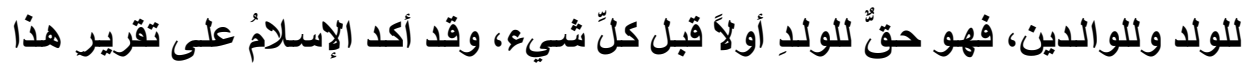

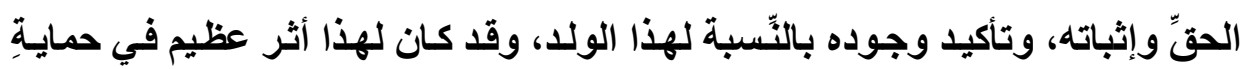

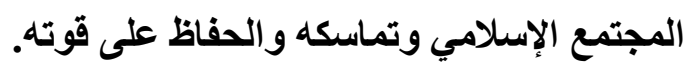

فحرص الإسلام على ثبوت النَّب، يرجع إلى سعيه علي الحفـاظ على الأسرة؛

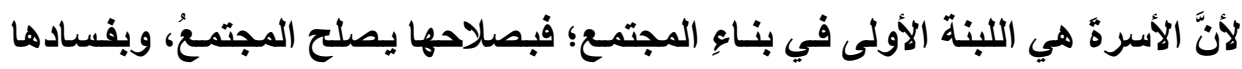

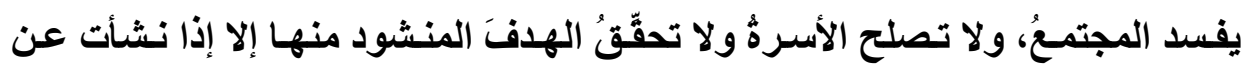
طريق الزَّواج الصحيح، وبهذا الزَّواج يكون النَّبَ.

(1) لمزيد من التفصيل راجع علي الإتترنت: http://www.alukah.net/sharia/0/40912, 12-10-2014. 
ولهـذا فقــ شـرع الله الـزَّواجَ لغايـاتِ سـامية، وأول هذه الغايـات بقـاء النـوع

الإنساني عن طريق شرعي، وعلى أكمل وجه، كما جاء في شريعتنا الغراء.

والنسب هو رابطة سـامية، وصلة عظيمة بين الأبناء والآبـاء. ولهذا عكفت

التشريعات الوطنية علي وضع قواعد حاكمة له بوصفه البنيان الحقيقي لوجود الأسرة التي تعد عماد أي مجتمع، كما نصت الاساتير الوطنية.

ولما كان نسبة الأبناء إلي ذويهم تعد السبيل الأول تمتعهم بالحقوق والتزامهر بالواجبات، فقد سعت المواثيق والاتفاقيات الدولية علي التأكيد علي أهمية نسبة الأبناء إلي ذويهه، بوصفه حق من حقوق الإنسان في معرفة أصوله وآبائه.

\section{أولاً: تعريف النسب لغة: - أنس}

يعرف النسب لغة بأنه مشتق من مصدر الانتساب، وقيل يقصد بـه الاتتساب

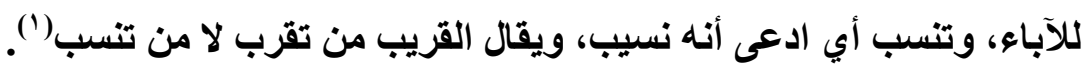

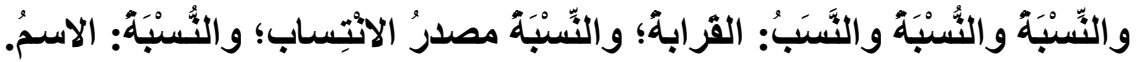

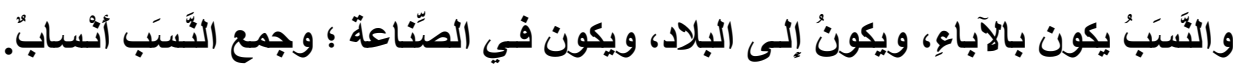

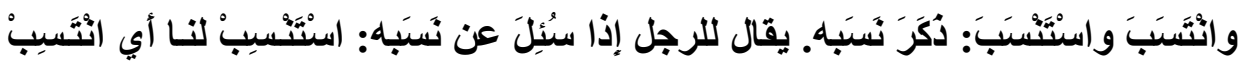

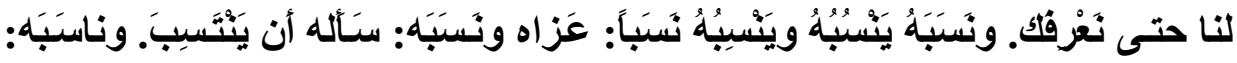

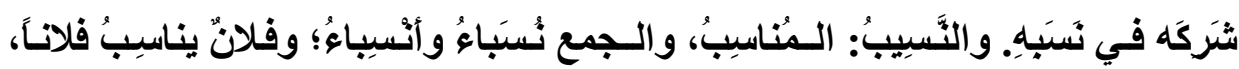

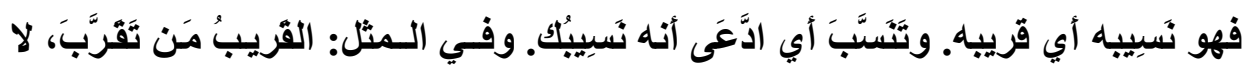

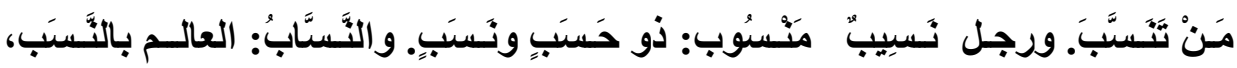

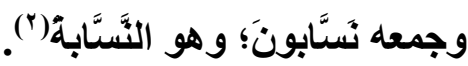

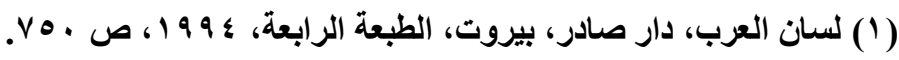

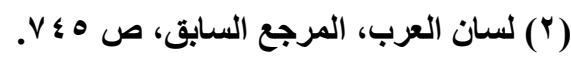




\section{ثانيًا: تعريف النسب اصطلاحًا:}

حاول الفقهاء وضع تعريف للمقصود بالنسب فعرفه ابن العربي بأنه "عبارة عن مزج الماء بين الذكر والأنثى على وجه الثرع، فِان كان بمعصية كان خلقًا مطلقًا،

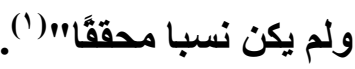

وعرفه المعاصرون بأنه "سلالة اللام أو رابطة سلالة اللام، وهي التي تربط الثخص بأصوله وفروعه وحواشيه("). والنسب هو أهم حق للأولاد على أبيهم، لأنهم

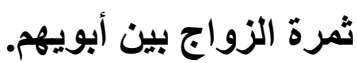

لابد من التفرقة هنـا بين النسب الشرعي والنسب الطبيعي، فالأول هو نـاتج

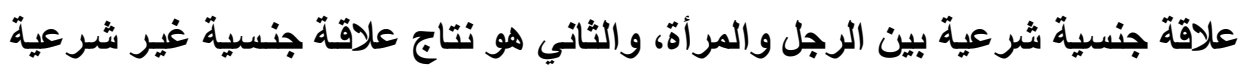

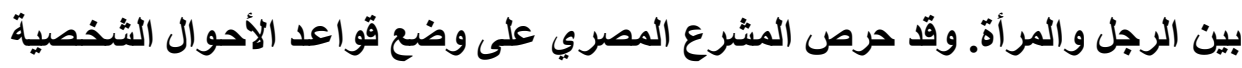
من خلال بيان الأسباب الشرعية لإثبات النسب حنى يكون صحيح خالي من العيوب التي التي

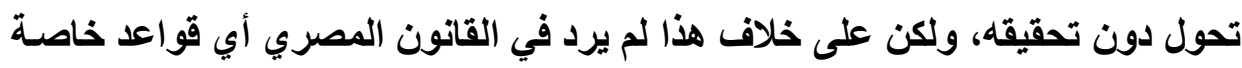

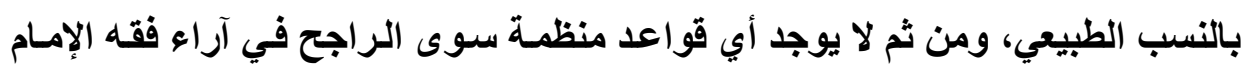

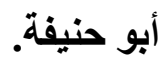

وقد حرص الإسلام على أن يكون الأبناء ثمرة لقاء شرعي من زواج صحيح

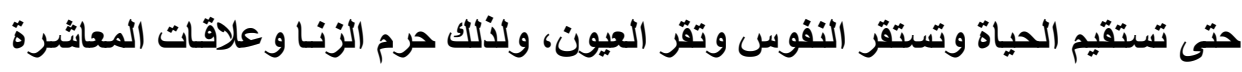

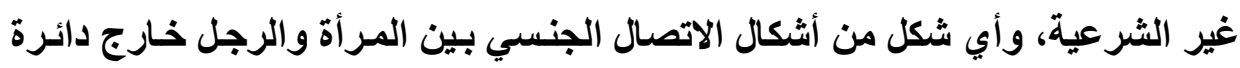

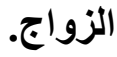

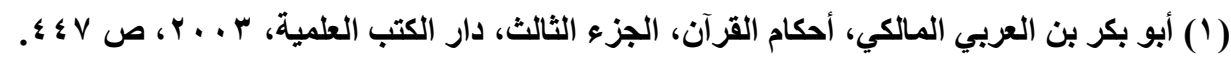

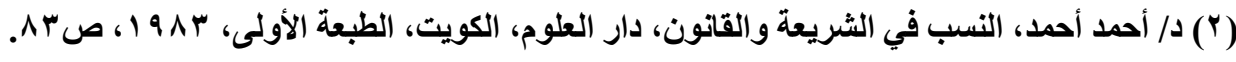


ولابد وأن نوضح هنا أنه يقصد بالنسب غير الشرعي ميلاد الطفل خـارج الإطـار الشرعي أي خـارج الرابطة الزوجية، إذ هو نـاتج عن علاقة غير شـرعية بين رجل وامرأة، أو تلقيح صناعي لامرأة دون أن تكون متزوجـة، أو متزوجة بـأخرى ــمـا في زواج المثليين - (')

ونقصد باثبـات النسب هنـا بيـان طرق ثبوت النسب، بـالفراش أو بـالإقرار، أو بالبينة أو حيازة الحالة، وكذلك محل الإثبات، وعبء الإثبات ومن يتحمل بـه، وشروط قبول دعوى إثبات النسب و إنكاره.

\section{ثانياً: هشكلة الدراسة:}

تعد مشكلة إثبات نسب بعض الأبناء لآبائهم من أهم المشكلات التي ظهرت في

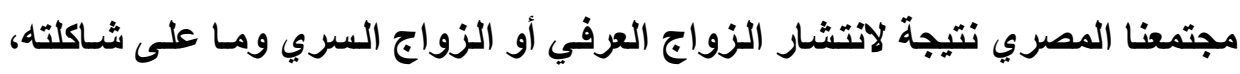
بالإضافة للحديث عن إمكانية نسب بعض الأطفال إلى غير ذويهم، فيمـا يعرف بالتبني. وقد بلغت أعداد دعاوى إثبات وإنكار النسب المنظورة أمام المحاكم المصرية فئ الآونة الأخيرة ما يقرب من ب ألف قضية وهو عدد جد خطير.

وإذا كانت مسألة إثبات النسب ثثير الكثير من المشكلات على الصعيد المحلي فالأمور تزداد صعوبة في مجـال تـازع القوانين، فقد يجد القاضسي نفسه أمسام قانون مختص أشـارت له قاعدة الإسناد لكنه يتعـارض في أحكامسه تعارضـًا صريحًا مـع النظام العام في دولته، مما يستوجب استبعاد هذا القانون(؟).

(1) هو زواج يعقد بين شخصين من نفس الجنس أو من نفس الهويـة الجنسية والاعتراف القانوني

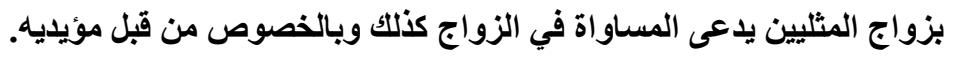

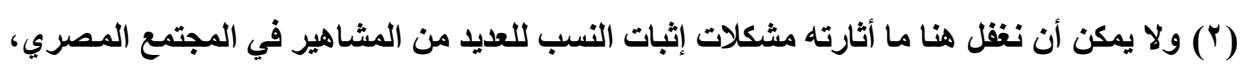
وتصدر ها لصفحات الجر ائد ووسائل الإعلام. 
إن المشكلة الأسساسية في علـم تنـازع القوانين هو الوصـول للقـانون الواجب التطبيق، فالعلاقة ترتبط بأكثر من دولة، والصعوبة تظهر في تعديد أنسب القوانين ليحكم هذه العلاقة.

ولكي يتسنى لنا تحديد القانون الواجب التطبيق، لابد من تحديد الضابط الذي سيرتكن إليه المشرع عند تحديد هذا القانون. ورغم كون مشكلة النسب من مسائل الأحوال الشخصية المهمة، إلا أن المشرع المصري لـم يورد قاعدة إسناد خاصـة بها،

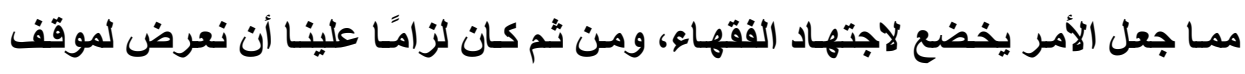
التشريعات المقارنة لتكون نصب عيني المشرع المصري عند تعديل قواعده، ووضـع قاعدة إسناد حاكمة لمسألة إثبات النسب.

\section{خطة الدراسة:}

وفقًا لما سبق، فإنتا نقسم دراستتا إلى مبحثين نعرض في الأول لطرق إثبات النسب في القانون المصري، ثم نبين في الثاني القانون الواجب التطبيق على إثبات النسب علي ضوء القانون المصري والتشريعات المقارنة. 
د ارشا على الدين أحمد

العدد 09 ( ابريل 17. (17) 


\title{
المبحث الأول \\ وسائل إثبات النسب في القانون المصري
}

\begin{abstract}
تمهيد وتقسيم:
إذا كانت مسألة النسب في حق المرأة بمجرد الميلاد سواء كان هذا الإنجاب

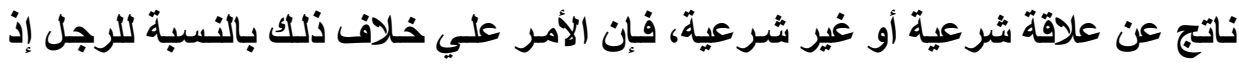
لابد من طرق محددة يثبت من خلالها، ولا يمكن إنكاره.

وقد فرق الفقه بين النسب الثرعي والنسب الطبيعي، فالأول يضمنه المشرع المصري ضمن مسائل الأحوال الثخصية وينظمه بقو اعد تتمثل في أسس شرعية يثبت

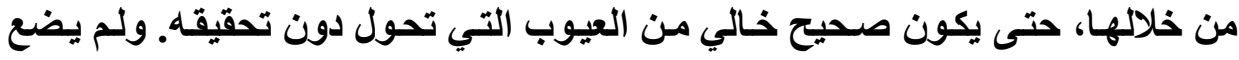

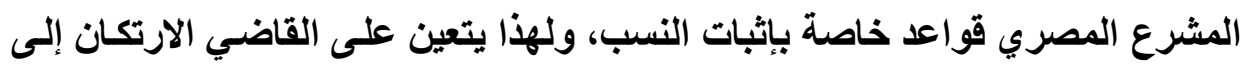

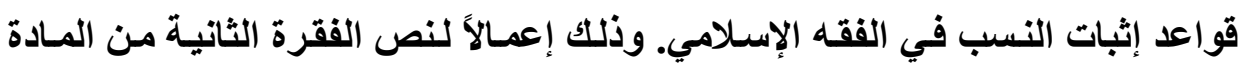
الثانية من القانون المدني "فإذا لم يوجد نص تشريعي يمكن تطبيقه، حكم القاضي لإني

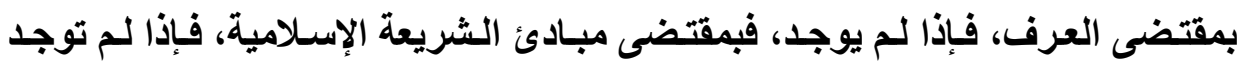
فبمقتضى مبادئ القانون الطبيعي وقواعد العدالة".
\end{abstract}

ولما كاتت الشريعة الإسلامية هي أساس مسائل الأحوال الثخصية في القانون

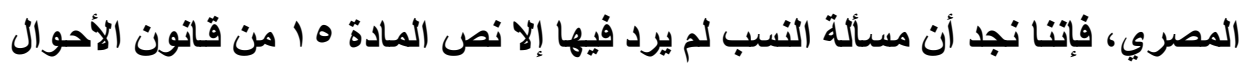

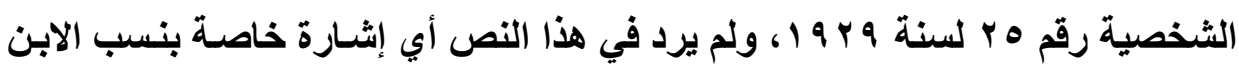

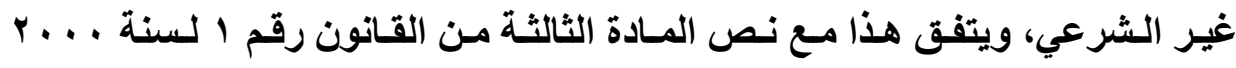

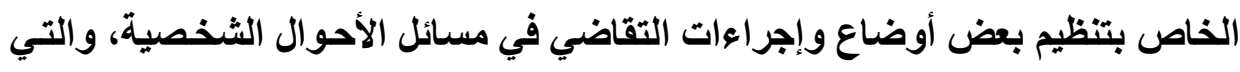


نصت علي أنه "تصدر الأحكام طبقًا لقوانين الأحوال الشخصية والوقف المعمول بها، ويعمل فيما لم يرد في شأنه نص في تلكاك القوانين بأرجح الأقوال من مذهب الإمسام أبي

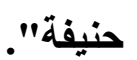

ولمــا كانـت أحكـام الفقـه الإسـلامي هـي أسـاس قواعد الأحوال الثخـصية في

القانون المصري، فالقاضي المصري ملتزم هنا بقواعد الثريعة الإسلامية وفةَّا لأرجح الأقوال من مذهب الإمام أبو حنيفة، ولهذا يتعين علينا أن نعرض لوسـائل إثبات النسب في القـانون المـصري مـرتكنين في هذا لقواعد الشريعة الإسـلامية الغراء بوصفها المصدر الرئيسي للقانون المصري عامـة ومسائل الأحوال الثخصية بصفة خاصـة. وسنحاول أن نعرض بإيجـاز دون الدخول في التفصيلات لقواعد النسب في الشريعة الإسلامية، موضحين الراجح من آراء الفقهاء.

وقد وضع الإسلام قواعد لنسب الأبناء، حتى يعرف الابن أباه وأمه. ويعد إثبات النسب للمرأة مجرد واقعة مادية تثبت في حق المرأة بمجرد واقعة الميلاد، سواء أكسان هذا الإنجـاب نـاتج عن علاقة شرعية أم غير شـرعية. ولكن الأمـر على خـلاف ذلك فئس بالنسبة للرجل إذ لابد من طرق ووسائل صحيحة وقانونية يثبت من خلالها، ومن ثم لا يمكن إنكاره إلا بالوسائل الثرعية، وأسس ثبوته تتمثل في عدة أسباب يمكن إجمالها في الفراش وما الحق به. وعلـي هـذا الأســاس نقسم حـديثنا هنـا لمبحثين، نعـرض فـي الأول لإثبـات النسب عن طريـق الفـراش (العلاقـة الزوجيـة)، ونعرض في الثـاني لوســائل إثبـات النسب بغير الفـراش. ولا نقـصد هنـا النسب غيـر الشرعي بـل النسب عـن طريـق الإقرار والبينـة والوسـائل العلميـة لإثبـات النسب أي النسب الذي لا يستتد لعقد زواج 


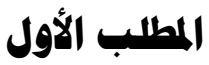

\section{إثبات النسب بالعلاقة الزوجية (الفراش)}

يقصد بالفراش لغة هو ما يفرش، يقال: الأرض فراش الأنـام، قال الله عز وجل

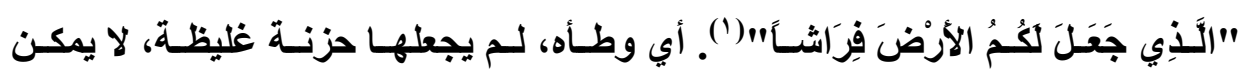
الاستقرار عليها، ومن المجاز: الفراش: زوجة الرجل، يقال لامرأة الرجل: هي فراشـه وإزاره ولحافه، لأن الرجل يفترشها(؟).

وقيل الفراش: اسم للزوج، فكل واحد من الزوجين يسمى فراشًَا للآخر، كمـا سمي كل واحد منهما لباستًا للآخر (ّ)، وقد يعبر بـه عن حالة الافتراش، افترشها، أي

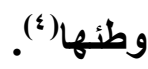

ويقصد بـالفراش اصطلاحًا "كـون المـرأة معنيـة للـولادة لشخص واحــ"(•)، ومعناه أن تكون هناك علاقة زوجية شرعية، قائمة بين رجل وامرأة، ينتج عنها حمل،

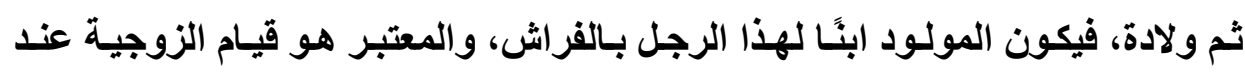
ابتداء الحمل، لا عند حصول الولادة"(").

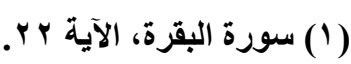

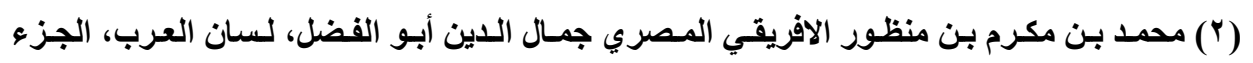

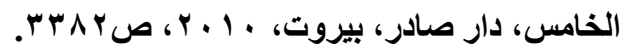

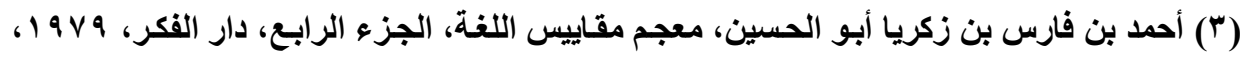

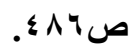

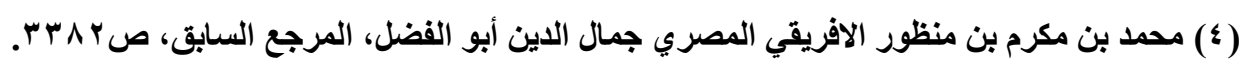

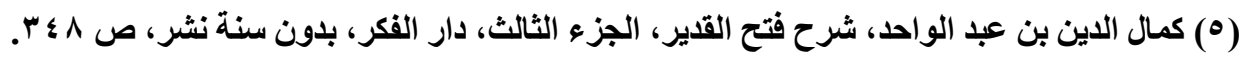

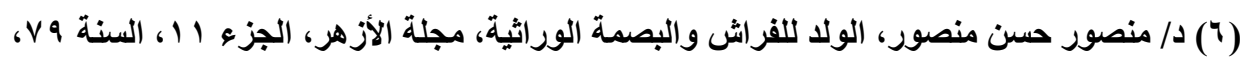


ومعنى الفراش هنـا هو النكاح الحقيقي الذي كـان الولـا نتاجِّا لـه، فهو تعبير

مهذب عن حالة اجتماع الرجل بالمرأة، حيث تكون المرأة كالفراش لزوجها. وتعد الزوجية الصحيحة السبب الرئيس لثبوت نسب المولـود الذي وضعته المرأة أثناء العلاقة الزوجية، دون الحاجة إلي اعتراف صريح من الزوج. يعني هذا أن الولا الذي تأتي به المرأة يلحق نسبه بمن يحل لها شرعًا جماعها، وهو الزوج.

\section{إثبات النسب في إطار عقد الزوواج:}

يُقصد بعلاقة الزوجية وجود علاقة بين رجل وامرأة، كلاهمـا زوجًا للآخر وفَّا لعقد شرعي، وقد يكون الإنجاب في هذه الحالة من خلال علاقة زوجية عاديـة أو حتى من خلال مـا يُطلق عليه التلقيح الصناعي بنوعيه الداخلي والخـارجي (')، وقد يحدث الإنجاب أثناء قيام العلاقة الزوجية، وقد تكون بعد الانفصال أو وفاة الزوج. فالزواج هو عقد يفبد حل استمتاع كل من العاقدين بالآخر علي الوجه المشروع.، فهو عقد يتضمن

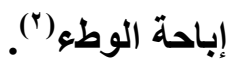

ويُطلق على إثبـات النسب في إطـار العلاقـة الزوجيـة، لفظ "إثبـات النسبب بالفراش"، والفراش هنا يُقصد به وجود علاقة شرعية بين رجل وامر أة، وهذه العلاقة

(1) التلقيح الصناعي هو عملية طبية تتمثل في إخصاب المرأة عن طريق حقن السائل المنوي للرجل

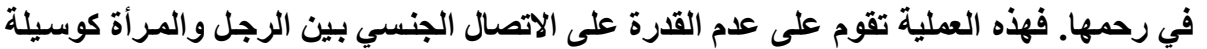

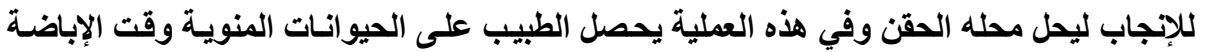

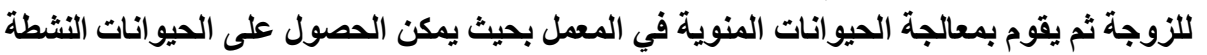

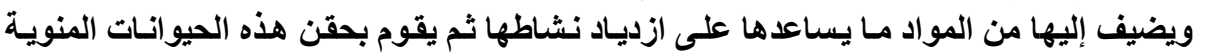

$$
\text { داخل الرحم بواسطة قسطرة رفيعة. }
$$

(Y) د/ أحمد نصر الدين الجندي، النسب في الإسلام والأرحام البديلة، دار الكتب القانونية، المحلة

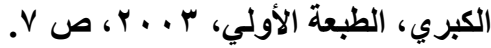




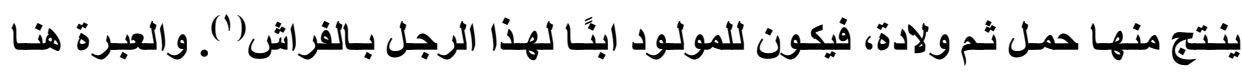
بوجود العلاقة الشرعية (الزواج) عند حدوث الحمل، لا عند حدوث الولادة. والأصل في معنى الفراش هو الزواج الحقيقي الذي منـه الولد، وهو لفظ يعبر

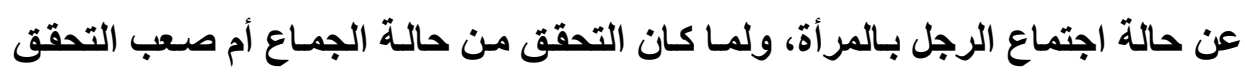
منه، فالأصل فيه السترة والخفاء، فاكتفى بمظنته، وهو قيام حالة الزوجية الممكنة، ومن ثم يحكم بثبوت النسب بمقتضاها. وهو الأمر الثابت بـالقرآن والسنة، يقول تعالى

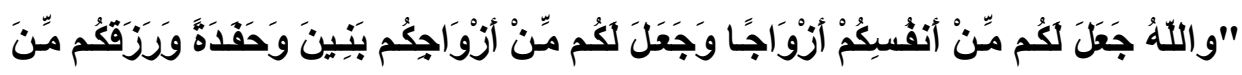

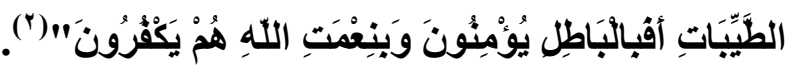
وروي عن عائشة رضي الله عنها قالت كان عتبة عهد إلى أخيه سـد أن ابن وليدة زمعة مني فاقبضه إليك فلما كان عام الفتح أخذه سعد فقال ابن أخي عهد إلي فيه فقام عبد بن زمعة فقال أخي وابن وليدة أبي ولا على فراشـه فتساوقا إلى النبي صلى الله عليه وسـلم فقـال سـعد يـا رسول الله ابن أخي قد كان عهد إلـي فيـه فقال عبد بن زمعة أخي وابن وليدة أبي ولد على فراشـه فقـال التبي صلى الله عليه وسـلم هو للك يا عبد بن زمعة "الولا للفراش وللعاهر الحجر" ثم قال لسودة بنت زمعة احتجبي منه لما رأى من شبهه بعتبة فما رآها حتى لقي الله. كما اتفقت الأمة على ثبوت النسب بـالفراش على جهة القطع، قـال الإمسام ابن الهيثم "وقد أجمعت الأمة على أن النسب يثبت بالفراش"(")، ومن ثم فإن النسب يثبت 
بقيام الزواج، دون حاجة إلى إقرار من الزوج أو بينة تقيمها الزوجة، ويتعين علينـا أن

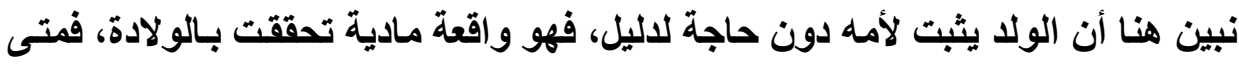

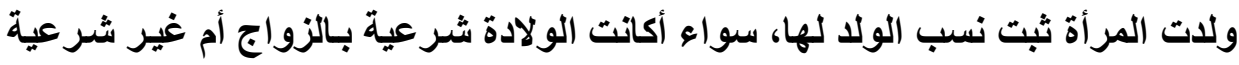

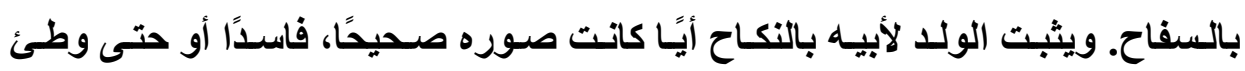

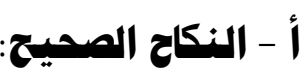

يُقصد به عقد الزواج المعتبر شرعًا، حيث توافرت أركانهه وشروطه، وانتفت موانعه(') و اتفق الفقهاء على ثبوت نسب الولد الذي يأني ثمرة لزواج صحيح ينسب

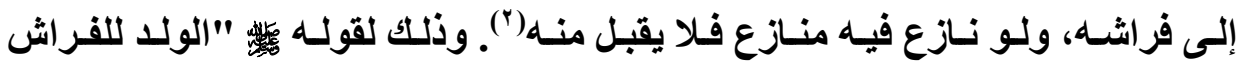

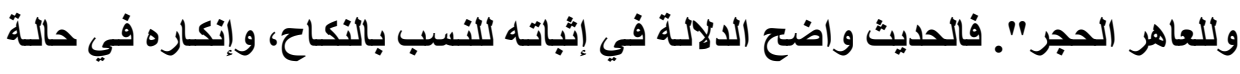

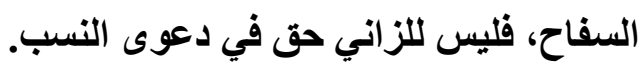
فيتبت الولا بالزواج وفقًا للشروط الآتية:

الشرط الأول: أن يكون الزواج صحيحًا وفقًا لأحكام القانون المصري، ولهذأ

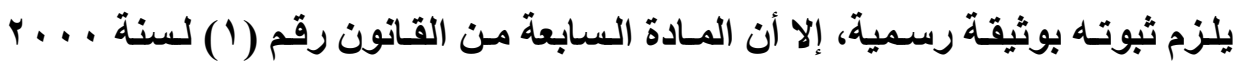

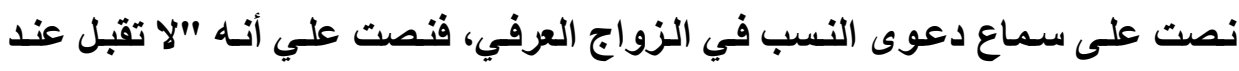

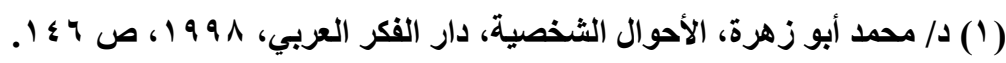

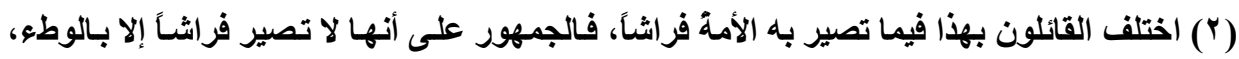

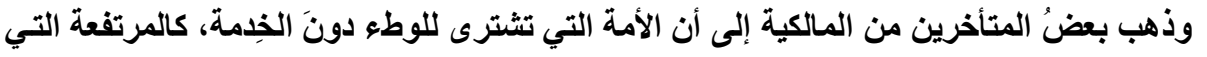

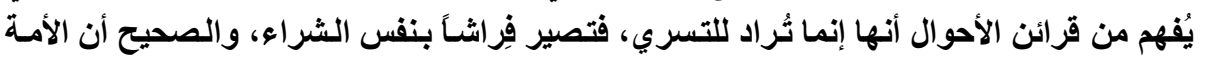

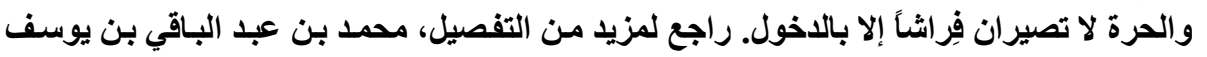

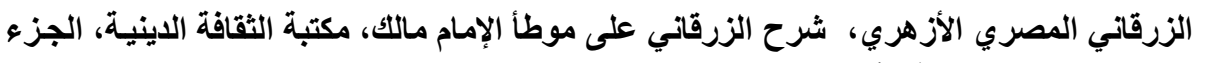

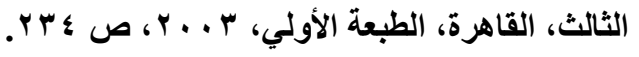


الإنكار دعوى الإقرار بالنسب أو الثهادة على الإقرار به بعد وفاة المورث إلا إذا وجلت أوراق رسمية أو مكتوبة جميعها بخط المتوفى و عليها إمضاؤه أو أدلة قطعيسة جازمـة تلال على صحة هذا الادعاء".

كما نصت الفقرتان الأولى والثانية من المادة الرابعة من القانون رقم ب ا لسنة

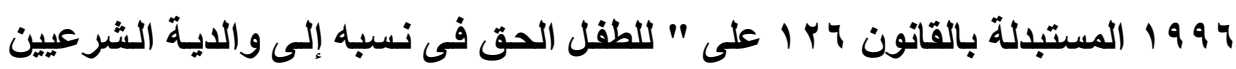
والتمتع برعايتهما، وله الحق في إثبات نسبه الثرعي إليهما بكافة وسـائل الإثبات بمـا

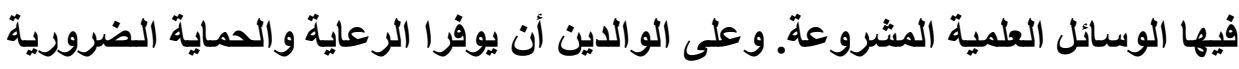
للطفل، وعلى الدولـة أن توفر رعايـة بديلـة لكل طفل حرم من رعايـة أسرته ويحظر التبني". ومن الوسائل العلمية الآن في إثبات النسب، البصمة الوراثية أو مـا يُعرف بـ

$$
\text { DNA }
$$

وقد قضت محكمة النقض المصرية بأنه "من الأصول المقررة في فقه الشريعة الإسلامية وعلى ما جرى به قضاء هذه المحكمة أن النسب يثبت بالفراش الصحيح وهو

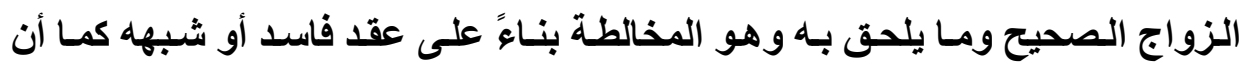
المقرر في الفقه الحنفي أن الزواج الذي لا يحضره شهود هو زواج فاسد يترتب عليه

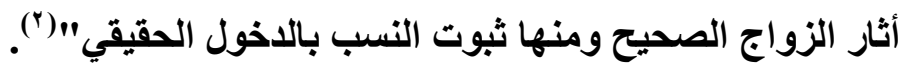

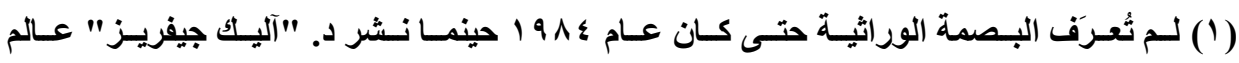

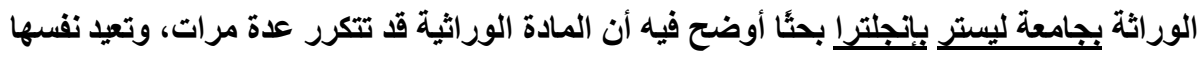

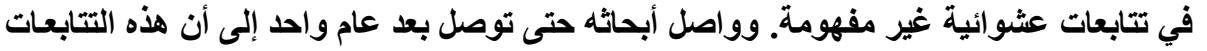

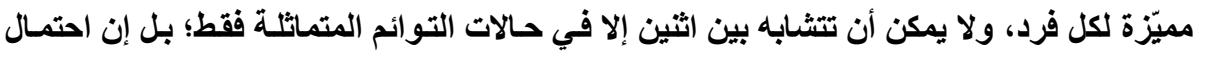

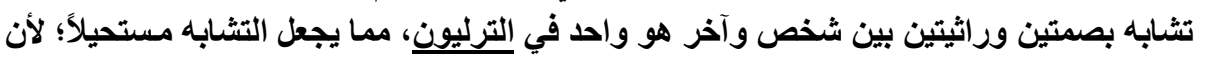

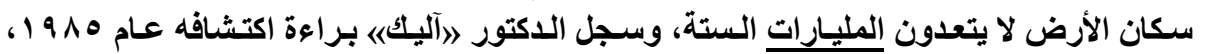

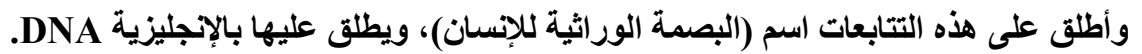

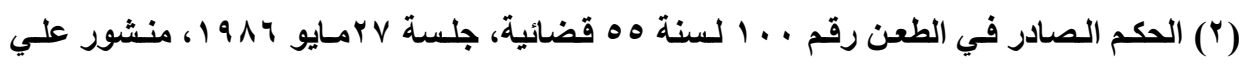
الإنترنت: (ب) - (ب) 
ولا عبرة لإثبات النسب ببقاء علاقة الزوجية أو انتهائها، فالعبرة بوجود العلاقة الزوجية الثرعية عند حدوث الحمل وليس ولادة الطقل. ففي حكم حديث قضت محكمة استنئنف القاهرة للأحوال الشخصية بأنه: "وحيث أنه لا يشترط في إثبات عقد الزواج تقديم هذا العقد بل يكفى أن يثبت بالبينة وقرائن الأحوال حصوله وحصول المعاشرة الزوجية تنفيذاً لـه، كمـا أنـهـ ليس بـاللازم أن يشهر الثهود مجلس ذللك العقد بل يكفى أن يشهدوا بعلمهم بحصوله لأن الشهادة بالتسامع جائزة. كمـا أن المقرر شرعًا أن النسب هو حق الله تعالى وهو من النظام العام وقد جرى الشارع على إثباته حتى إذا دار الأمر بين ثبوتها ونفيه وترجح جانب الإثبات وتقبل فيه الثهادة حسبة ويغتفر فيه التناقض لما قد يصاحبه من لبس أو إخفاء وتجوز فيه الثهادة بالثائع ويترتب النسب فى نكاح فاسد إذ الأصل أن النسب يحتال في إثباتهـ بمـا هو جـائز عقلاً وقبولـه شـرعاً لحمل المرأة على الصلاح صيانة لشرفها وشـرف عثيرتها وللتستر على الأعراض وإحياء للولا مراعاة لمصلحته"('). كما قضت محكمة النقض المصرية بأنه "أن دعوى النسب متميزة عن دعوى إثبات الزوجية وأن إثباتها لا يخضع لما أورده المشرع في المادة 99 من لائحة ترتيب

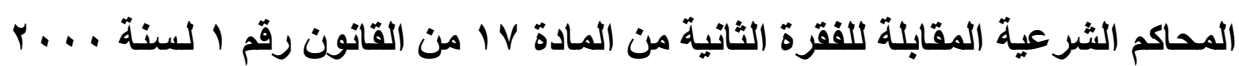
بتظظيم بعض أوضساع وإجراعات التقاضسي في مسائل الأحوال الشخصية من قيد على سماع دعوى الزوجية أو الإقرار بها مما مفاده أنه لا يشترط لإثبات النسب وجود وثيقة

http://www.cc.gov.eg/Courts/Cassation_Court/Civil/Cassation_Court_Civil .aspx.

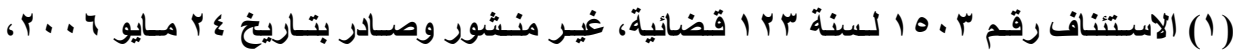
استيناف القاهرة. 
زواج رسمية، كما أنه ولئن كـان من المقرر أنها لا تقبـل عند الإنكار الدعاوى الناشئة عن عقد الزواج ما لم يكن الزواج ثابتًاً بوثيقة رسمية إلا أن دعوى النسب مستثناة من هذه الدعاوى، ولا تخضع - وفقا لما سلف بيانه ـ من قيل على سماع دعوى الزوجية ولا

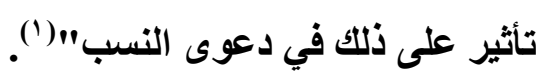
ومن المقرر في القانون المصري ومـا استقر عليه القضاء المصري أن العقد الباطل لاتتفاء شروط الانعقاد لا يترتب أي أثر من أثار الزواج الصحيح فلا يحل بـه دخول، ولا يجب بـه مهر، ولا يستحق بمقتضاه نفقة ولا طاعة ولا يثبت توارث ولا نسب لمولود.

السشرط الثـاني: أن يكون الزوج ممن يتصور منـه الحمل عـادة: بـأن يكون الزوج يمكن أن يحدث منـه الحمل للزوجـة، فبان لـم يكن الزوج أهلاً للإنجـاب، فلا يتم ثبوت نسب المولود له، وذلك كالصغير، وكذلك من كان لايه عاهة تجعله غير قادر على الإنجاب(). فيقصد هنا المخالطة الجنسية بين الزوجين بعد إبرام عقد الزواج الصحيح ذلك أن العقد وحده لا يكفي إذ لابد من الدخول الحقيقي والتلاقي بين الزوجين. ومن ذلك أيضًا عدم إمكانة التلاقي بين الوالدة والوالد، وقد ورد في المـادة 1

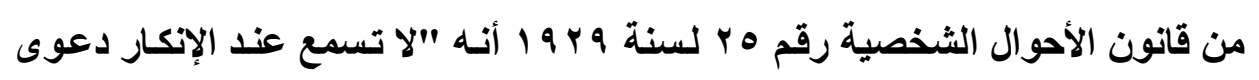
النسب لولا زوجة ثبت عدم التلاقي بينها وبين زوجها من حيث العقد، ولا لولد زوجة

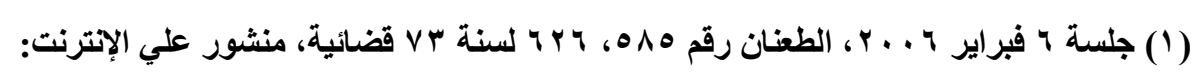
http://www.cc.gov.eg/Images/Madany/2006/2/585-73/585-73.pdf (r) أبو إسحاق إبرا هيم بن علي بن يوسف الشيرازي، المهذب، الجزء الثالث، دار الكتب العلمية،

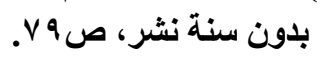


أتت به بعد سنة من غيبة الزوج عنها، ولا لولا المطلقة والمتوفى عنهازوجها إذا أتت به لأكثر من سنة من وقت الطلاق أو الوفاة". فالمشرع المصري منع عند الإنكار سماع دعوى النسب لولـ زوجة ثبت عدم التلاقي بينها وبين زوجها من حين العقد ، ولا لوللا زوجة أتت بـه بعد سنة من وقت غيبة الزوج عنها.

فالجنين يحتاج إلي البقاء في بطن أمسه مدة يتكون فيها بنـاؤه، وتتم أعضاؤه حتى يخرج إلي الحياة بشرًا سويًا، وقد جرت العادة بـأن النساء يلدن لتسعة أثـهر، وقلما ينقص عن ذلك ونادرًا ما يزيد. الشرط الثالث: أن يولا الولا بعد ستة أشهر فأكثر من الزواج: وتلك أقل مدة للحمل، فإن ولا الولا لأقّل من ستة أثـهر واستمرت حياته ـ دون مساعدة طبية ـ كمـا يحدث الآن طبيًا في الـولادات المبكرة داخل الحضانات، فـلا يثبت نسبه مـن الزورج بإجماع الفقهاء، لأن ذلك دليل على أنه ت بالحمل قبل الزواج(') كما اتفق الفقهاء على أن أقل مدة الحمل ستة أشهر، والاليل على رأيهم: قولـه

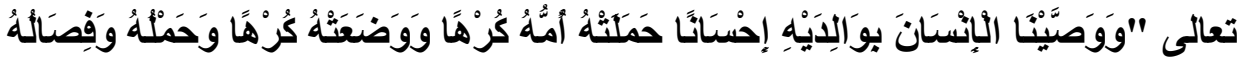

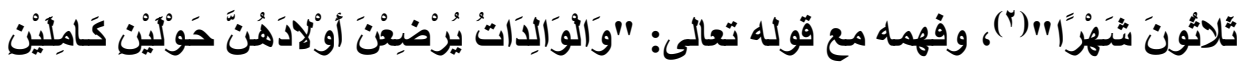

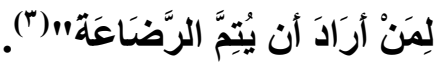

(1) أبو زكريـا محيي الدين يحيى بن شرف النووي، روضة الطالبين، المكتب الإسـلامي، بيروت،

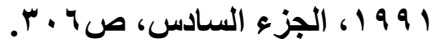

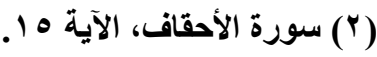

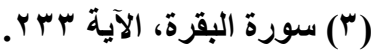


فوفقَا للنص القرآنسي فِإن مجموع الحمل والإرضـاع ثُلاثين شـهراً وكانت مدة الرضاع منه سنتين كان الباقي في المدة وهو ستة أشـهر متعينًا للحمل. وهو مـا يتفق مـع مـاروي عن أن عمر رضسي الله عنه قـال أن امرأة وللات لستة أشـهر، فهم عمر برجمها، فقـال لـه علي بن أبي طالب رضـي الله عنه: ليس للك ذلك. قـال الله تعـالى: "والوالدات يرضعن أولادهن حولين كـاملين"، وقـال تعالى: "وحملـه وفصاله ثلاثون شهرًا" فحولان وستة أشهر ثلاثون شهرًا، لا رجم عليها، فظلى عمر سبيلها، وولدات مرة أخرى للذلك الحـل. ومـن هنـا ذهب الاتجـاه أن المرأة إذا ولدت حـال قيـام الزواج الصحيح ولا لأقل من ستة أشـهر من تـاريخ العقد عليها لا يثبت نسب هذا الولد من زوجها، لأنها حملت به لم تكن زوجته إلا إذا ادعاه وأقر أنه ابنه، ولم يقل أنـه ابنه مـن

الزنا فيثبث نسبه(') - (1)

ورغـم وقـوع الاتفـاق بالإجــاع علــي أن أقـل مــدة للحمـل هـي سـتة أشـهـر،

إلا أن الأمر لم يكن كذلك بالنسبة لأقصي مدة الحمل، وهذا لسبب وحيد مرجعه أن أقصي مدة للحمل لا دليل عليه من الكتاب والسنة. ولهذا اختلفت الآراء الفقهية في هذا الثَأن.

فذهب الظاهريـة إلـي أن أقصي مـدة حمـل هـي تسعة أشـهر، وهو أقرب إلـي

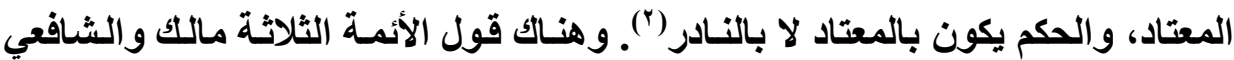
وابن حنبل بأن أقصي مدة للحمل هي أربع سنين، وسندهم في ذلك ما رواه الدار قطني،

(1) د/ رمسضان علـي السشرنباصى، أحكـام الأسـرة فـي السشريعة والقـانون، دار الجامعـة الجديـدة،

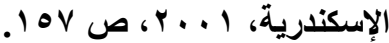
(r) د/ خليفة علي الكعبي، البصمة الوراثية وآثار ها علي الأحكام الفقهية، دراسة مقارنة، دار الجامعة

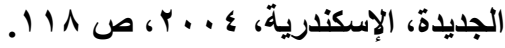


عن مالك بن أنس أنه كان يقول جارتنا (مرأة محمد عجلان، امرأة صدق وزوجها رجل

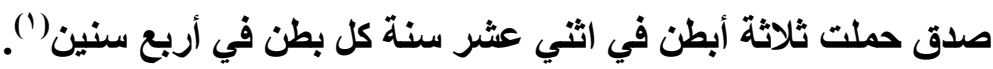
وذهب رأي ثالث إلي أن أقصي مدة للحمل هي سنتان، واستّل هذا الرأي بقول

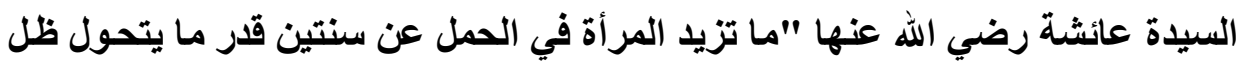

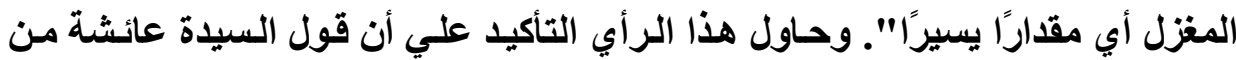
الراجح أنها سمغنه من المصطفي صلي الله عليه وسلم("). وقد أخذ المشرع المصري خروجًا على المذهب الحنفي في القانون رقم هب

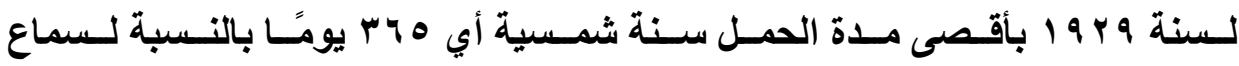

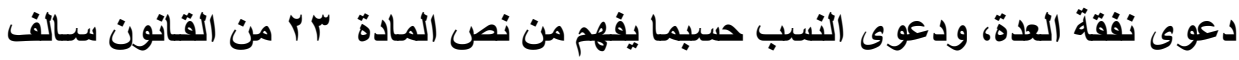

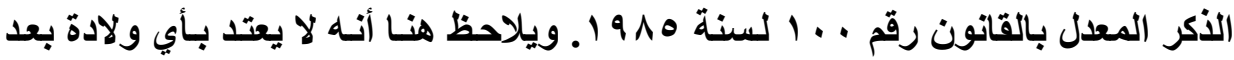

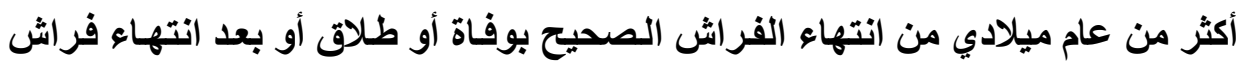

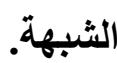

الثرط الرابع: إمكان تلاقي الزوجين بعد العقد: يتخلق الولد بتلاقي ماء الرجل

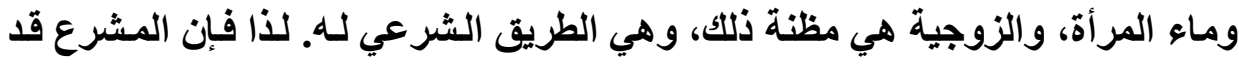

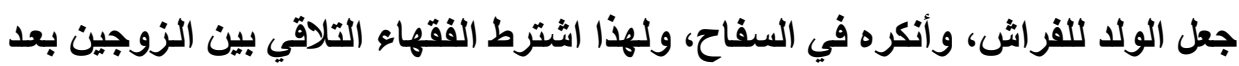
العقد، لإثبات النسب بينهما، إلا أنهم اختلفوا في تفصيل هذا الشرط")

(1) دم دمد محي الدين عبد الحميد، الأحوال الثخصية في الشريعة الإسـلامية، المكتبة العلميـة،

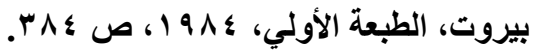

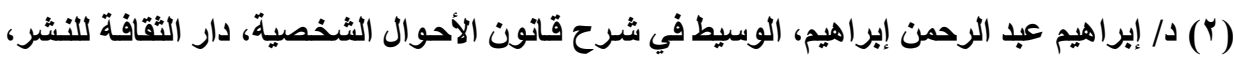

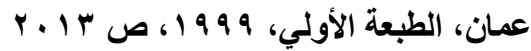

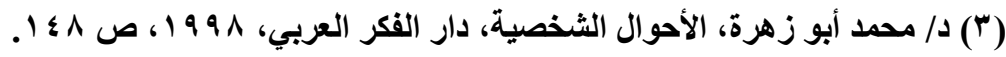




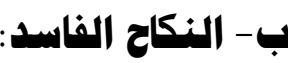

يعتبر النكاح الفاسـ كالنكاح الصحيح في ثبوت النسب إذا اتصل بـه الـخول الحقيقي نتج عنه الولا، فإنه يترتب عليه إلحاق النسب احتياطيًَا لإحياء الولا. ويعرف النكاح الفاسد بأنـه النكاح الذي فقد شرطا من شروط الصحة مثل ذلك كالعقد بغير شهود(')، والزواج المؤقت (زواج المتعة)، الزواج بـلا شهود، زواج المعتدة دون علم

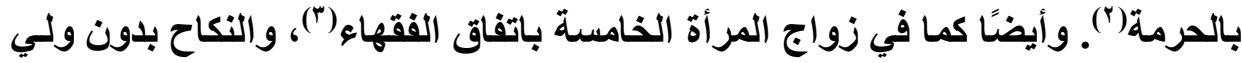

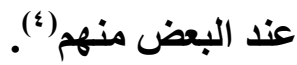
والزواج الفاسـد شـأنه شـأن الزواج الصحيح، إذ يشترط فيهه مدة الحمل، إلـي جانب الاخول الحقيقي. ويترتب على هذا الزواج الفاسد التفرقة بين الزوجين، مع ثبوت النسب حماية لمصلحة الولا خشية من ضياع نسبه، مـع ضرورة توافر بقية شروط ثبوت النسب في الزواج الصحيح من دخول حقيقي بالمرأة، ومضي أقل مدة حمل. ج - الرطو بالشبهة: يُقصد به كل معاثرة بين رجل وامرأته، ليس بنـاء على عقد زواج صحيح أو فاسد وليست زنا حتى لا توجب الحد، أو هو الوطء المحظور الذي لا يوجب حدًا، لقيام ( (1) د/ وهبة الزحيلي، موسوعة الأحوال الثخصية حسب آخر التعديلات، الجزء الأول، دار الوفاء،

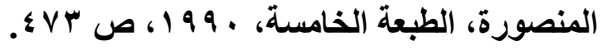

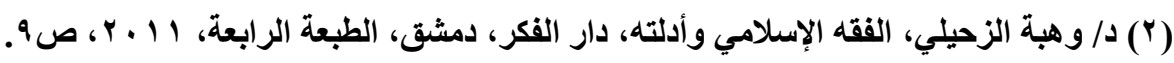

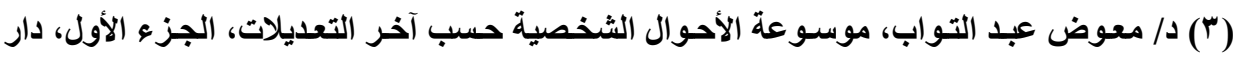

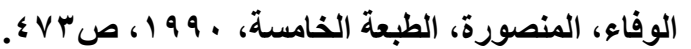

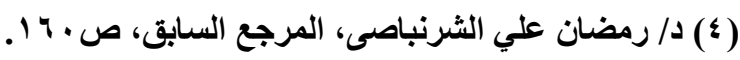


شبهة ترتب عليه انتفاء قصد الزنا(') فهو نكاح يقع خطأ بسبب غلط يقع فيه الثخص. وهو يختلف عن الزنا في حسن النية، فحسن النية هي التي تلعب الاور الفاصل، فالزنـا لا يثبت به النسب لأنه آثم ولا يعطي الله نعمته بمعصية(؟). ويثبت النسب من الوطء بالشبهة عند جمهور الفقهاء(")، إذا جاءت بـه المرأة ما بين أقل مدة حمل وبين أكثرهـا. فالنكاح بشبهة علي أنواع ثلاثة هي: أولها شبهة الملك، وفيه يشتبه الـليل الشرعي علي الرجل فيفهم الإباحة، كمـا في مواقعة رجل

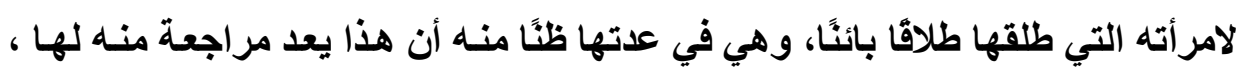
كما في المطلقة طلاقا رجعيًا. وثانيها شبهة العقد، فحاصلها أن يعقد الرجل علي امرأة، وياخل بها دخول حقيقي، وهو يعتقد أنها تحل له ثم يتبين له بعد ذلك أنها لـم تكن تحل له، كما لو تبين أنها أخته في الرضـاع. وثالثها شبهة الفعل، فحاصلها أن يواقع رجل امرأة علي أنها زوجته ثم يتبين بعد ذلك أنها ليست زوجته(؛). تلك كانـت أسس وشـروط اكتساب النسب بنـاء علـي عقد الزواج (الفراش) بوصفه الأسـاس الأول لاكتسـاب النسب. ولكن السؤال المهم هل هنـأك طرق وأسس أخري لاكتساب النسب؟ وهو ما نجيب عنه في المطلب التالي. 


\section{المطالب الثاني \\ وسائل إثبات النسب}

نقصد بوسـائل إثبــات النسب هنـا الإقرار والبينـة والوســائل العلميـة الحديثـة وسوف نعرض لكل من هذه الطرق بمزيد من التفصيل.

أولاً: الإقرار بالنسب:

يقصد بـالإقرار إخبار الشخص عن ثبوت حق عليه لشخص آخر، وهو أيضًا

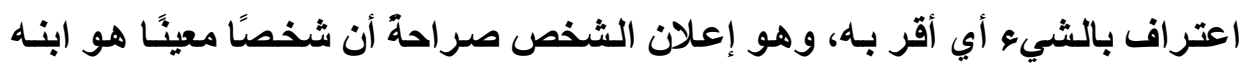
سواء كان المقر رجلاً أو امرأة، وسواء كان المقر له ذكرًا أو أنثي ('). من المقرر شرعًا أنه إذا صدر إقرار من الزوج في عقد الزواج الصحيح نسب

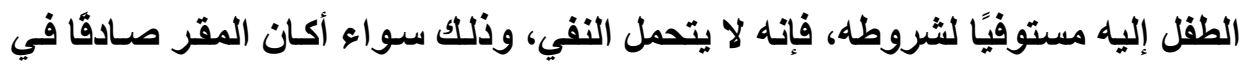

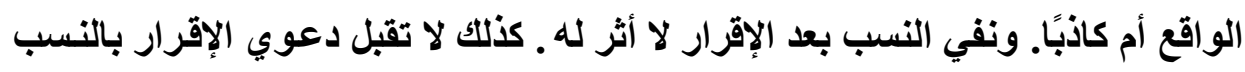

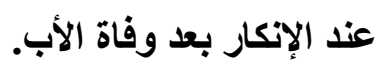

ولهذا نصت المادة V من قانون الأحوال الثخصية لسنة ... Y على أنه "لا

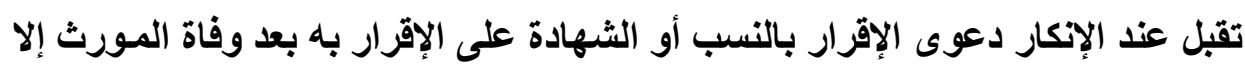

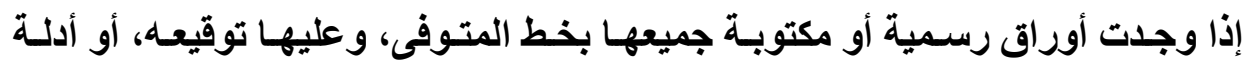
قطعية حازمة تدل على صحة هذا الادعاء".

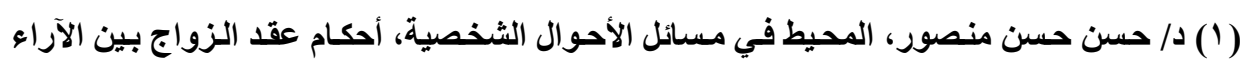

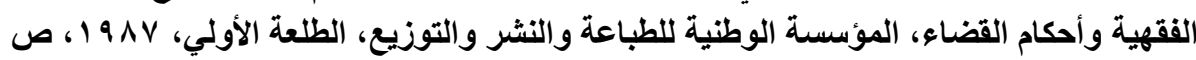


ويلاحظ هنـا أن النسب يثبت في حالـة الزواج بالبينة كذلك، ويُقصد بهـا هنـا شهادة رجلين أو رجل وامرأتين، وتكون شهادتهما على توافر الزواج والفراش بمعنـاه

الصحيح.

$$
\text { ويمكنتا القول بأن هناك نوعان للإقرار في إثبات النسب: }
$$

أ - الإقرار المتعلق بذات المقر (')، هو إقرار بـالبنوة أو الأبوة أو الأمومـة، والنسب

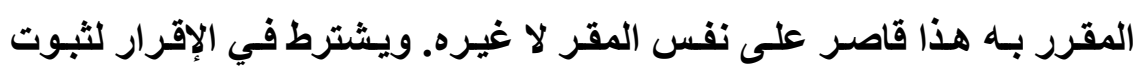

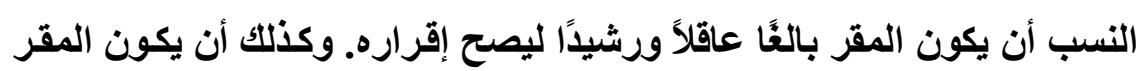
له مجهول النسب، أي لا يكون معروف النسب من أب غير المقر، وأيضًا أن تكون الأبوة أو الأمومـة أو البنوة ممــ يشهر بهابـا الواقع فـلا يتصور أن يكون الفارق العمري بين المقر والمقر له ثلاثة أعوام مثّلًا. ويلزم بجانب هذا أن يكون المقر حيًا، وألا يصرح أن المقر له ابنا من زنا أو بطريق التبني (). بـ الإقرار بالنسب المحمول على الغير، يقصد به إقرار الغير بنسب غيره، فكما في إقرار شقيقين بنسب آخر إلى أبيهم. والراجح هو عدم ثبوت النسب بمثل هذا

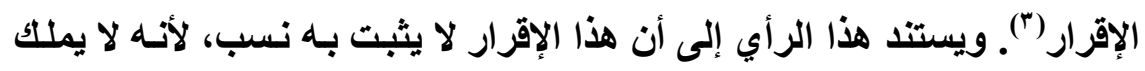

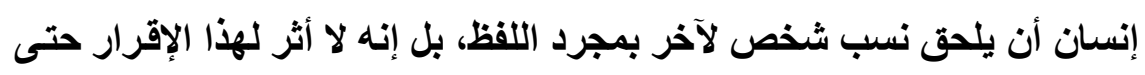

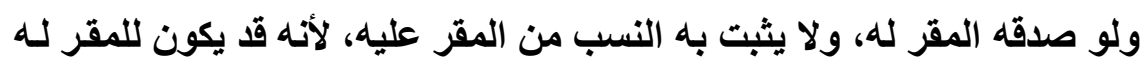
مصلحة من هذا التصديق، فهو إداّ من من يجلب النفع لنفسه(؛). 


\section{ثانيًا: إثبات النسب بالبينة: ا}

هي أحد الوسائل الخاصة باثبات النسب، والمراد بها المحافظة على مصلحة

$$
\text { الصغير وروابط الأسرة. }
$$

ويُقصد بالبينة الدلاثل والحجج التي تؤكلد وجود واقعة مادية وجودًا حقيقيًا

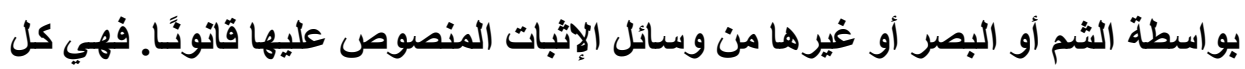
دليل يمكن استعماله لإثبات النسب كالكتابة واليمين والقرائن وشههادة الشهود، وتلكك

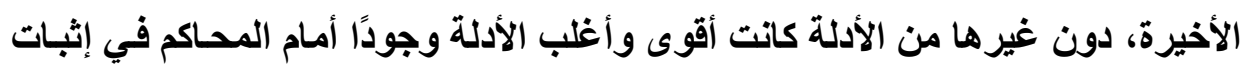

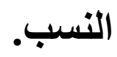

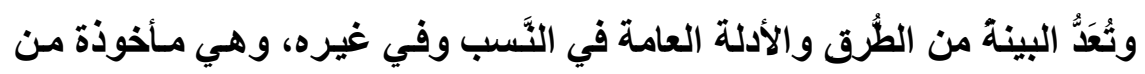

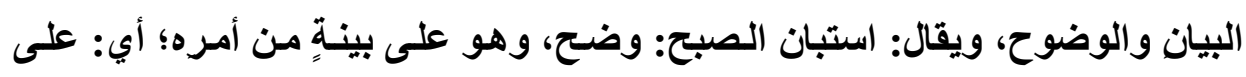

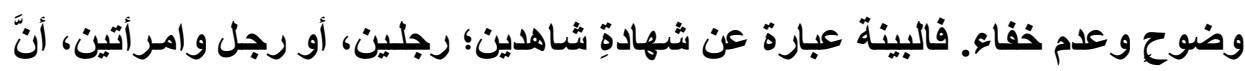

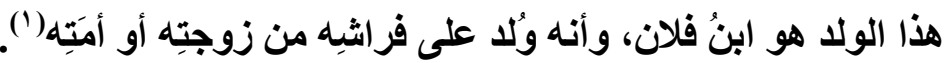
والبينة أقوي من الإقرار من حيث ثبوت النسب، وإن كان قد ثبت بـالإقرار فهو غير مؤكد يحتمل البطلان، لأنها أقوي منه. فتمتاز البينة علي الإقرار بأنها حجة متعدية

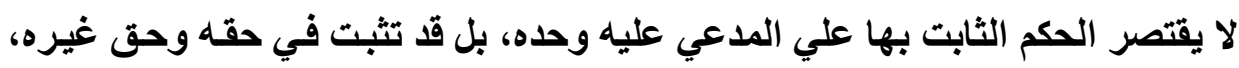
أما الإقرار فهو حجة قاصرة علي المقر لا تتعداه إلي غيره.

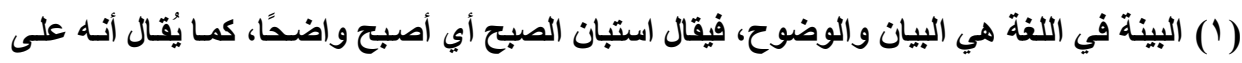

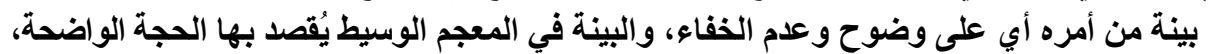
والتماس البينة أي طلبها والبحث عنها والقضاء بالبينة أي الحكم من خلالها الألئ. 
وقد قضت أحكـام محكمـة النقض المصرية بصحة الشهادة على وجـود عقد

الزواج وقيام العلاقة الزوجية حتى ولو لم يعاين الثـاهد العقد متى اشتهر عند الشـاهد ذللك طبقاً للمذهب الحنفي المعمول به في مصر في دعاوى الأحوال الشخصية عند عدم وجود نـص فقد جـاء في أحد أحكامها: "العشرة أو المساكنة لا تعتبر وحدها دليلاً شرعيًا على قيام الزوجية والفراش، وإنما نص فقهاء الحنفية على أنه يحل للشاهد أن يشهر بالنكاح ولو لم يعاينه متى اشتهر عنده بأحد نوعى الشهادة الشرعية الحقيقية أو الحكمية فمتى شهر أن رجلاً وامرأة يسكنان في موضع أو بينهما انبساط الأزواج وشهر لايه رجلان عدلان بلفظ الشهادة أنها زوجته حل لـه أن يشهد بالنكاح وإن لـم يحضر وقت العقد، وهذا عند الصاحبين أمـا عند أبى حنيفة فلا يجوز للشـاهد أن يشهـ على النكاح بالتسامع إلا إذا اشتهر شهرة حقيقية وهى ما تكون بالتواتر" (1". كما قضت في حكم آخر لها "أن المقرر ـ في فقه الأحناف ـ أن النسب كمـا يثبت في جانب الرجل بالفراش فإنه يثبت بالبينة الشرعية ذلك بأن ثبوت النسب من حق الله ويقبل فيه ما لا يقبل في غيره حتى لو قالت لا شـهود لي ثم أحضرت شـهوداً قبل ذلك منها فأولى إذا لم تقل ذلك وتقدمت بالإثبات فإنـه يكون مقبولاً بـالأولى فضلاً عن ذلك فإن النسب مما يخفى ويقبل فيه ما لم يقبل في غيره"(『).

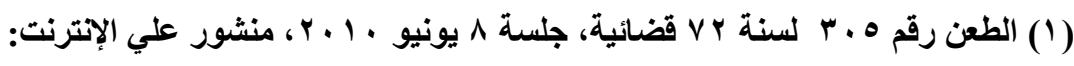
http://www.cc.gov.eg/Courts/Cassation_Court/Civil/Cassation_Court_Civil .aspx.

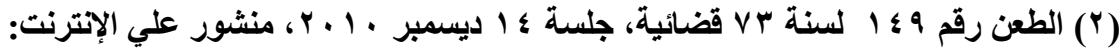
http://www.cc.gov.eg/Courts/Cassation_Court/Civil/Cassation_Court_Civil .aspx. 


\section{ثالثًا: إثبات النسبب بالطرق الملميبة:}

أفسـح التطور التكنولوجي والعلمي المجال أمام استحداث وسـائل جديدة للكشف عن الأبوة أو الأمومة من خلال طرق علمية متطورة أهمها ما عُرف بالبصمة الوراثية. ويُقصد بالبصمة الوراثيـة البنيـة الشخصية نسبة إلى الجينـات أو المورثـات التفصيلية التي تلدل على هوية كل فرد بعينه، وهي وسيلة تمتـاز بالدقة، حيث إنها لا تكاد تخطئ في التحقق من الأبوة البيولوجية والتحقق من الشخصية"' (1). ورغم الاراسات الطبية التي تؤكد دور البصمة الوراثية DNA في إثبات ونفي النسب، فمساز ال المشررع المسصري يقف صسامتًا حيـال الأخـذ بهـا، ومـاز الت المحساكم المصرية تستند إليها على سبيل الطمأنينة وليس على سبيل القطع، ويرتكن إليها القضاء كدليل لإثبات النسب في حالات الزواج الفاسد، ولكن لا يمكن القول بإمكانية الأخذ بها في إثبات نسب أطفال الزنا (الأطفال غير الشرعيين). ويجوز إثبـات النسب بالبصمة الوراثية، ولكن الحسال علي غير ذلك في نفي النسب، فلا يجوز شرعًا الارتكان إلي البصمة الوراثية، حيث إن التحاليل البشرية قد يعتريها الخطأ البشري. أما إثبات النسب بهذه البصمة فلا يكون إلا في عقد صحيح لا يتم اللعان فيه بين الزوجين فإن تم اللعان فاللعان أقوى من البصمة الوراثية (). (1) د/ حافظ محمود، دور البصمة الوراثية في تحديد النسب، دار القبة للنشر والتوزيع، ب . ب؟، ص1/

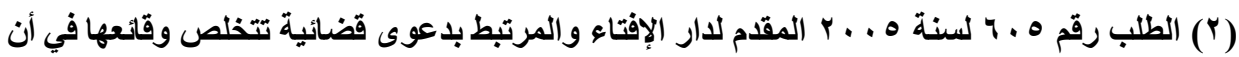

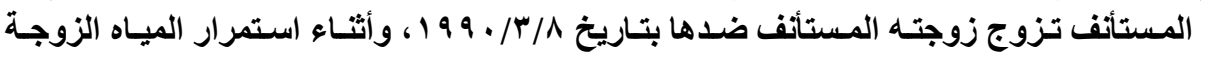

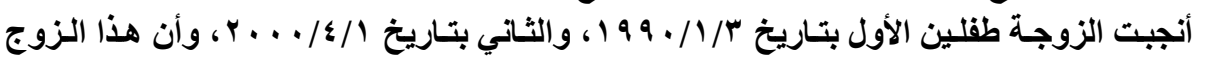

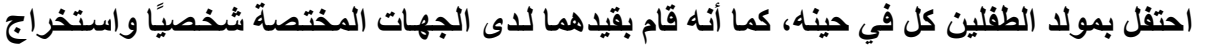

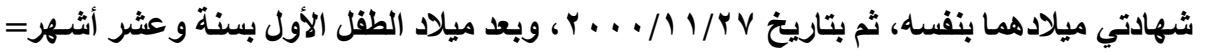


يغني هذا أنه يثترط لإثبات النسب عن طريق التلقيح الصناعي توافر الشروط

$$
\text { 1 - أن يكون الزواج شرعيًا. }
$$

rـ أن يتم التلقيح برضا الزوجين وأثناء حياتهما.

$$
\text { rـ أن يتم بمني الزوج وبويضة رحم الزوجة دون غير هما. }
$$

عرضنا في هذا المبحث لأكثر طرق إثبات النسب شيوعًا، والسؤال المهم الآن

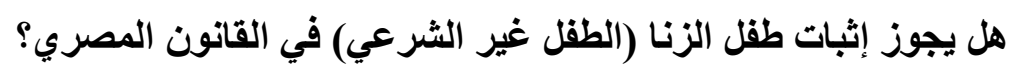

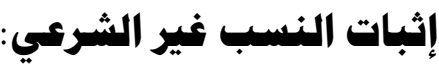

يُقصد بالنسب غير الشرعي، ميلاد الطفل خـارج الإطـار الشرعي أي خـارج

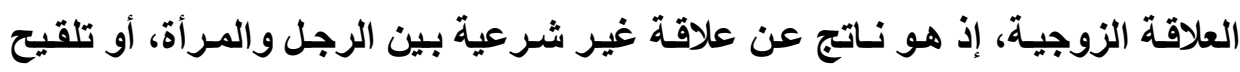

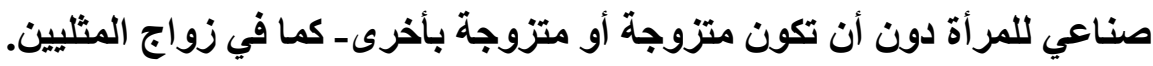
وقد يتظلى الآباء عن هؤلاء الأطفال، ويظهر الطفل اللقيط، فهو المولود الذي

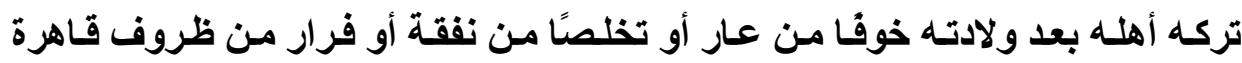

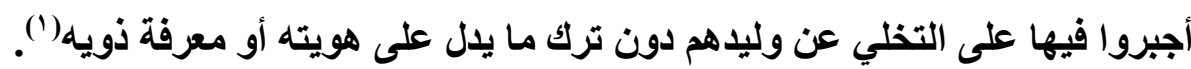

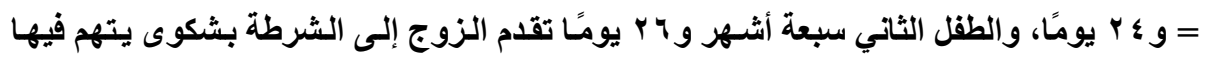

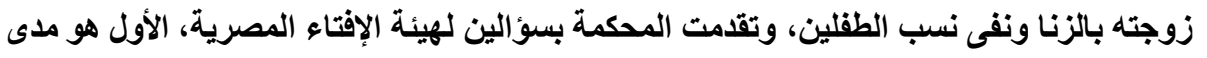

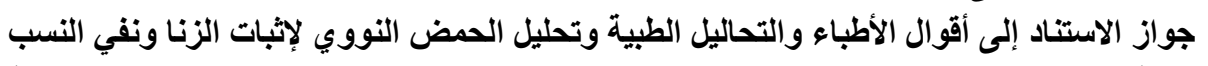

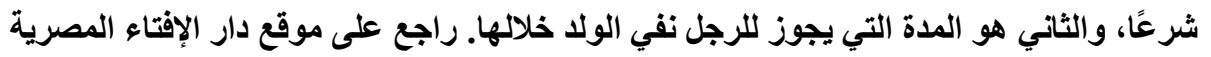
www.dar-alifta.gov.eg.

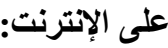

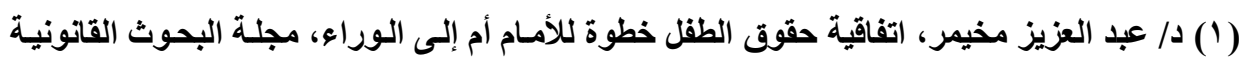

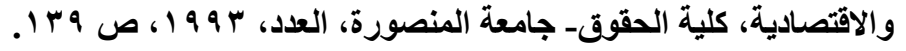


ولما كاتت الثريعة الإسلامية هي أساس مسائل الأحوال الثخصية في القانون

المصري، فإنتا نجد أن مسألة النسب لم يرد فيها إلا نص المادة ه 1 من قانون الأحوال الثخصية رقم ه r لسنة و ج 9 1، ولم يرد في هذا النص أي إثارة خاصة بنسب الطفل غير الشرعي أو اللقيط. ولمـا كانت أحكام الفقه الإسـلامي هي أسـاس قواعد الأحوال الشخصية في القانون المصري فيتعين علينا أن نعرض لموقف الفقه الإسلامي. وقد اتفق الفقه الإسلامي ـ كما بينا سابقًا ـ على أن الولا الذي يولد على فراش الزوجيـة ينسب لأبيـه لقول المصطفى صلى الله عليهه وسـلم "الوللد للفر اش وللعـاهر الحجر"، أي أنه لا يجوز نسبة ابن الزنا للأب.

فإثبات نسب الولا الناتج من علاقة غير شرعية غير وارد باتفاق الفقهاء، حتى لو أثبتت فحوصات البصمة الوراثية نسبه إليه؛ لأن الزنا لا يصلح سبيًا لثبوت النسب؛

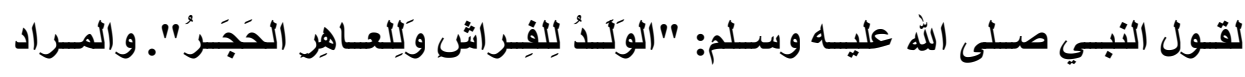

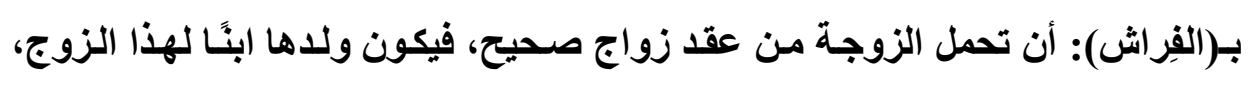
والمراد بـ(العاهر): الزاني. لكن يجب أن يُنسب ولا الزنا لأمه فقط، فيجب تعريفه بأمسه؛ لما بينهما من الحقوق المتبادلة كحق الميراث والحضانة وحرمـة المصاهرة وغيرهـا من الحقوق.

عرضنا في هذا المبحث لأسس إثبات النسب في القانون المصري، سواء أكاتت من خلال فراش الزوجية أم وسائل إثبات النسب بغير فراش الزوجية. ويتعين علينـا أن نبين هنا أنتا لم نعرض لوسـائل نفي النسب نظرًا لكون دراستنا قاصرة علي القانون الواجب التطبيق علي إثبات النسب. 
د ارشا على الدين أحمد

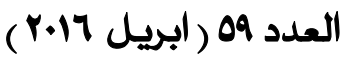

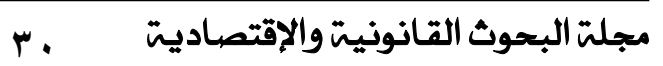




\title{
المبحث الثاني
}

\section{القانون الواجب التطبيق على هسائل النسب}

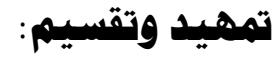

أوضـــا سـابقًا بـأن المقصود بالنسب الشرعي، النسب المنبثق عن علاقة

زوجية صحيحة، أي نسبة الولا لأبويـه المتزوجين، ولابـد وأن نبين هنـا أن المشرع المصري لم يورد أي قاعدة تنازع تحدد القانون الواجب التطبيق على النسب.

ومن ثم، يتوجب علينا البحث عن القانون الواجب التطبيق في ضوء النصوص الخاصة بتنازع القوانين في القانون المصري، ويمكنتا القول بـأن البنوة الشرعية هي نتاج الزواج، ومن ثم تعد من مسائل الأحوال الثخصية. وإذا كـان قانون الجنسية هو أساس قواعد الإسناد في شتى المسائل المتعلقة بالأحوال الشخصية، فالسؤال هل نعتد بجنسية الأب أم الأم أم الوليد؟ والسؤال المهم هل يختلف القانون الواجب التطبيق على النسب الثرعي عن القانون الواجب التطبيق على النسب الثرعي. وعلى هذا الأساس فإنتا نقسم هذا المبحث لثلاثة مطالب: المطلب الأول: القانون الواجب التطبيق على النسب الثرعي. المطلب الثاني: القانون الواجب التطبيق على النسب غير الثرعي. المطلب الثالث: نطاق تطبيق القانون الواجب التطبيق على النسب
\end{abstract}




\section{المطاب الأول}

\section{القانون الواجب التطبيق على النسب الشرعي}

حاول الفقه البحث عن أنسب القوانين للتطبيق على النسب الشرعي، ويمكن القول بأن الأمر لا يخرج عن فرضين، الفرض الأول: هو اتحاد جنسية الولا مـع المراد الانتساب إليه من الأبوين (الأب أو الأم). وهنا لا خلاف في أنه سيطبق قانون جنسيتهما المشتركة.

أمسا الفرض الثاني فيتمثل في اختلاف جنسيتهما، ولكن قبل الحديث عن هذا الفرض نجد أن التشريعات المقارنة اتخذت عدة حلول يمكن إجمالها في الآتي:

\section{أولاً: تطبيق القانون الشخصي للابن:}

يذهب هذا الرأي إلى تطبيق القانون الثخصي للولا المراد إثبات نسبه، دون

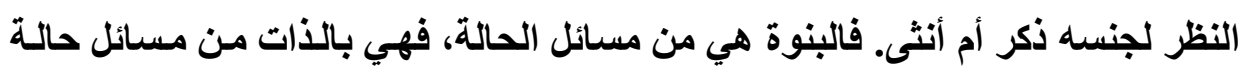

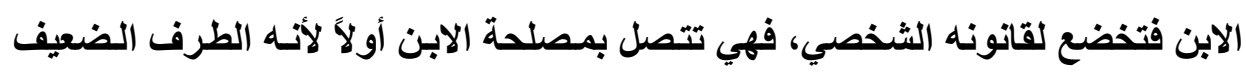
في هذه العلاقة(') ولكن في المقابل نجد رأي آخر يرد علي هذه الحجة بقوله بأن أبوة

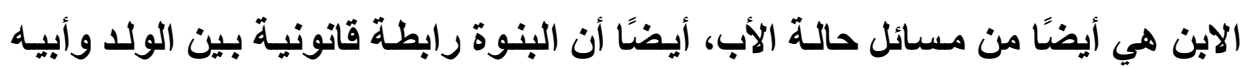
وأمه وتتجم عنها حقوق والتزامات متبادلة، ولكل من الطرفين مصلحة فيها لذا لا تصح التضحية بمصلحة شخص لحساب شخص ونم آخر ().

(1) L.HARRIS, The Basis for Legal Parentage and The Clash between Custody and Child Support, See at,

https://mckinnevlaw.iu.edu/ilr/pdf/vol42p611.pdf, 10-8-2014.

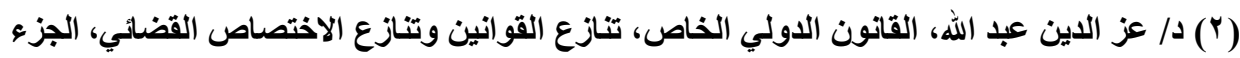

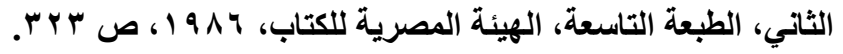




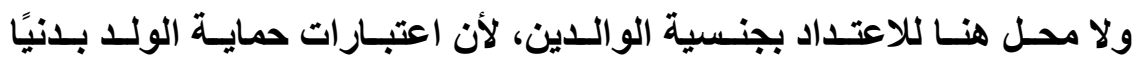

وروحيًا، تعلو على حجة الرأي القائل بضرورة تنظيم الروابط العائلية واتصال ذلك بدورها في الأسـرة، وهذا كـان ترجيح اختيـار القـانون الشخصي بوصفه قـادرًا على تحقيـق هـــه الاعتبـارات('). ومـن التشريعات التـي أخــت بهـذا الـرأي، القــانون

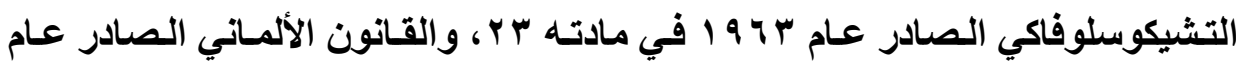

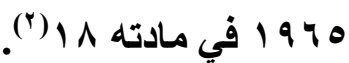

\section{والسؤال ها هو المتصود بالقانون الشخصي للابن المراد إثبات نسبه؟}

ير اد بـه قانون الدولة التي يكون بها محل الإقامـة العاديـة للابن("). وهو مـا

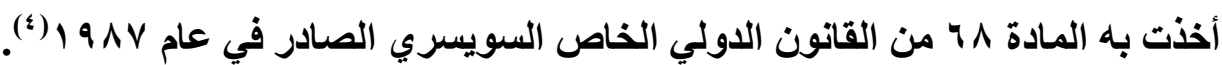

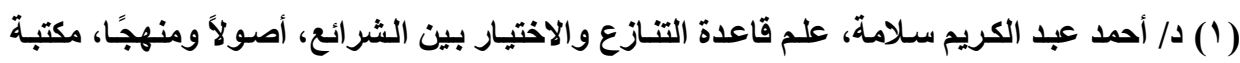

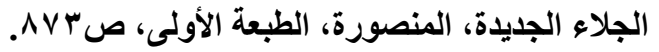

(2) For more Details, See at, http://www.hse.ru/data/2012/06/08/1252692468/SwissPIL\%20в\% 20ред.\%202007\%20\%28англ.\%29.pdf

(3)L.SILBERMAN, The Hague Convention on Child Abduction and Unilateral Relocations by Custodial Parents, A Perspective from the United States and Europe - Abbott, Neulinger, Zarraga, See at, https://www.law.ou.edu/sites/default/files/files/OU_LAW_ADMIN/07\%2 0silberman\%20article\%20blu4.pdf, 8-10-2014.

(4)K.SAARLOOS, European Private International Law on Legal Parentage, Thoughts on a European Instrument Implementing, The Principle Of Mutual Recognition in Legal Parentage, Degree of Doctor, Maastricht University, 2010, P.156.

مجلة البحوث القانونيتّ والإقتصاديتة ب 


\section{ثانيًا: تطبيق القانون الشخصي للأم:}

ذهب هذا الرأي إلى إخضاع البنوة الثرعية لقانون جنسية الأم على اعتبار أنها

في غالب الأحيان المحور الأساسي لكل الدعاوى المتعلقة بالنسب(')، كما إنه من النـادر أن تكون مجهولـة بخـلاف الوضـع في حالـة الأب. وهـو الـرأي الذي أخــ بـه المشرع

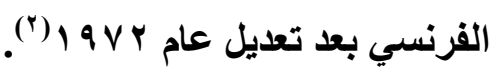

فقد اعتد المشرع الفرنسي بقانون جنسية الأم وقت الميلاد، علي أسـاس أهمية

دور الأم في العلاقات الأسرية، بالإضـافة لكون الأم معروفة بخـلاف الأب. كذلك تطبيق هيق قانون الأم يضمن تطبيق القانون الفرنسي في أغلب الحسات المعروضـة علي القضاء. فالإحصائيات تكثف عن أن المرأة المتزوجة من فرنسي ـ في الغالب ـ تكتسب الجنسية

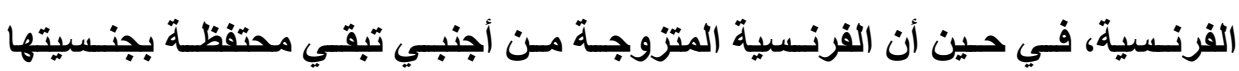

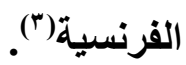

والعبرة هنـا بقـانون جنسية الدولـة التي تنتمـي لهـا الأم وقت ميلاد الابن (๕)؛

ويستند هذا الرأي إلى حجة مؤداهـا أن هذا الحل يؤدي إلى توحيد القانون الواجب التطبيق إذا تعدد الأبناء، واختلفت جنسياتهم عن جنسية أمهم، وهو ذات ما يحدث عند

(1)K.SAARLOOS, P.R., P.129.

(2) H.WISE \& L.AMON, Paternity Suits under French Law, See at, http://www.immigration-france-usa.com/gifs/pdf/paternity.pdf, 2-102014.

(3) BOUREL(P.) et les autres, Droit International Privé, Dalloz, Paris, 10e édition, 2013, P.262.

(4) L.SILBERMAN, P.R., P.12.

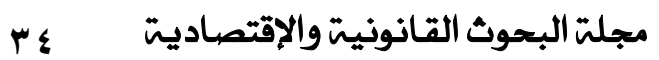


حدوث تنازع قوانين في مجال إثبات النسب غير الثرعي، ففي الحالتين يسري قانون

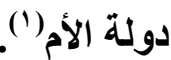

ويُضاف إلى هذه الحجج حجة أخرى هي أن هويـة الأم مؤكدة بوصفها واقعة

مادية، كما يكفل تطبيق قانون القاضسي على كافة حالات النسب الناثـئة عن العلاقات التي يكون أحد أطرافها وطنيًا. وقد أخذ بهذا الاتجاه بصفة أصلية القانون الفرنسي في

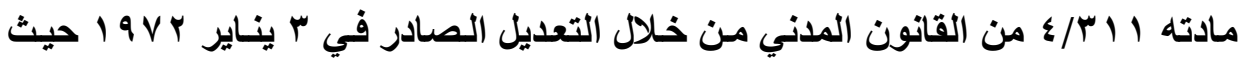
نصت المادة على "يحكم النسب القانون الثخصي للام يوم ميلاد الولا، فإذا لم تكن الأم معروفة، فالقانون الثخصي للولا(؟). ويلاحظ أن النص هنا لم يفرق بين إثبات النسب

$$
\text { الشرعي والنسب غير الشرعي. }
$$

وقد آثز القانون الألماني تطبيق قانون الأم على نسب الطقل ولم يميز بين الطقل مـن الزواج الشرعي والطفل مـن خـارج إطسار الـزواج("). والحسال كـلكك في القـانون الإيطالي فلا تمييز بين الطقل الشرعي والطقل غير الشرعي، ومن ثم ينطبق القانون الوطني للأبوين أو لأي منها لحظة الميلاد. ممـا يعني أنه جعل الخيـار للقاضي فله أن يطبق القانون الوطني لهما إن اتحدا في الجنسية أو لقانون الأب أو لقانون الأم(؛).

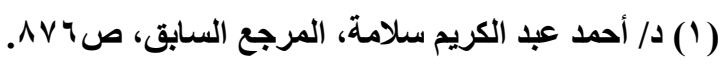

(2)H.WISE \& L.AMON, Paternity Suits under French Law, See at, http://www.immigration-france-usa.com/gifs/pdf/paternity.pdf, 2-102014.

(3) K.SAARLOOS, P.R., P.165.

(4) F.PESCE, Diversity in a United World of Child Support, Country reports, Italy, See at, http://www.heidelbergconference2013.de/tl_files/downloads-abstracts/abstracts-ab-3-32013/Abstract_PESCE.pdf, 12-10-2014. 


\section{ثالثًا: تطبيق القانون الشخصي للأب:}

يخضع هذا الاتجاه النسب الشرعي، لقانون دولـة الأب اعتباره هو السبب في

وجود الابن، والأب هو رب الأسرة، بالإضافة إلى أن تطبيق هذا القانون يضمن وحده

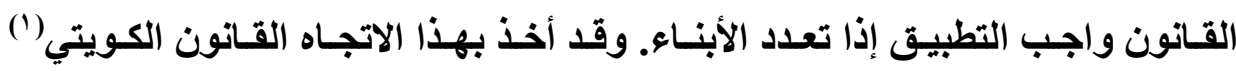

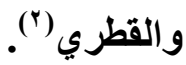

\section{ولكن السؤال ها هو المقصود بقانون دولة الأب؟}

ذهب القانون الأسباني في مادته 9/ء من القـانون المدني إلى أن المقصود بـه

هو قانون جنسية الأب وقت ميلاد الابن(")، وذهب القانون الدولي الأمريكي إلي أن

المقصود به قانون الدولة التي يتوطن بها الأب وقت ميلاد الابن(؛).

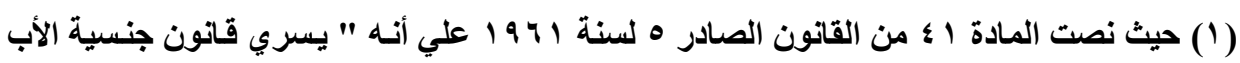

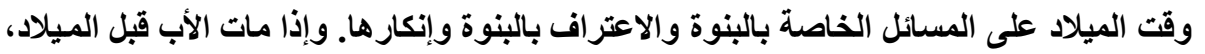

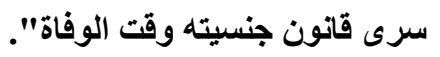

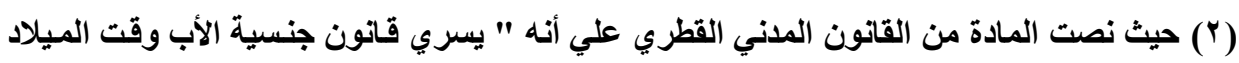

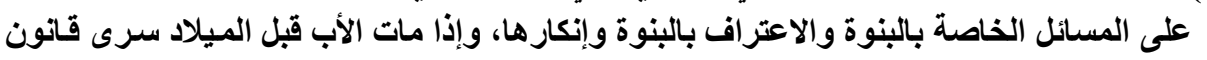

$$
\text { جنسيته وقت الوفاة". }
$$

(3)P.MOZOS, Recognition in Spain of Parentage Created by Surrogate Motherhood, Yearbook of Private International Law, Vol.12, 2010, P.622.

(4)J.ESTER, Illegitimate Children and Conflict of Laws, Indiana Law Journal, Vol.36, Issue 2, 1961, P.164.

مجلت البحوث القانونيت والإقتصاديت 


\section{رابعًا: تطبيق القانون الشخصي للوالدين:}

يخضع هذا الاتجاه البنوة الشرعية للقانون الشخصي للوالدين، باعتبار أن الابن

المراد إثبات نسبه الشرعي هو نتاج علاقة الزوجية الصحيحة، والأمر يتصل بذلك

العلاقة ووجودها، وتنظيم الأسرة.

ويقصد بقـانون الدولـة التـي ينتمـي إليهـا الوالـان بجنسيتهما إذا كانـا متحـدا

الجنسية، القانون الذي كان يحملا جنسيته لحظة ميلاد الابن إذا كانت علاقة الزوجية

مازالت قائمة بينهما، أو وقت اتحلال هذه الرابطة إذا كاتت عرى الزوجية قد انفصمت.

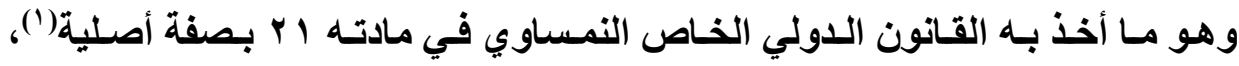

وبصفة احتياطية المادة ^ ؟/ץ من القانون الدولي الخاص السويسري(؟).

وهو قانون الدولة التي يتوطن بها الوالدان، إن اختلفت جنسيتهما، وهو ما أخذ

به القانون الدولي الخـاص اليوغسلافي في مادتهـ . ـ("). وقد أخذ القانون الهولندي

بقانون الجنسية المشتركة للزوجين وقت ولادة الطفل، فإن كانـا مختلفا الجنسية فمكان

إقامتهما المعتاد، فِان لم يكن لهما مكان إقامة معتادة فقانون محل إقامة الطقل (๕).

(1)K.SAARLOOS, P.R., P.282.

(2)C.SUMNER, Private International Law Aspects of Homosexual

Couples: The Netherlands Report, See at,
http://www.ejcl.org/111/art111-8.pdf, 12-11-2014.

(3)A Study of Legal Parentage and the Issues Arising From International Surrogacy

Arrangements,

See

at, http://www.hcch.net/upload/wop/gap2014pd03c_en.pdf, 3-6-2014.

(4)J.ESTER, P.R., P.167. 
وذات الأمر جاءت به نصوص القانون المدني اليوناني فنصت على أن القانون

الثخصي للأب والأم عند ولادة الطفل هو الواجب التطبيق على نسبه، ولكن عاد ليضع

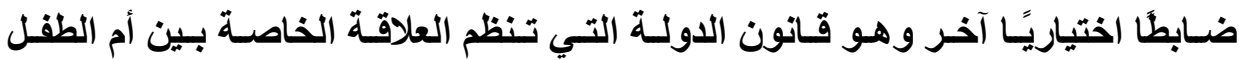

وزوجها، إذا كان الزواج قد انتهى، نظرًا لاعتبار الزواج أثرًا من آثار هذا الزواج) '(')

\section{خاهسا: تطبيق جنسية الأب والابن همًا:}

ذهب هذا الاتجاه إلى القول بإخضاع البنوة لقانون جنسية الأب وقانون جنسية الابن معًا تطبيقًا جامعًا (†). ويعاب علي هذا الرأي أنه يؤدي إلى تطبيق الأحكام المتفقة في القانون دون تلك المتعارضة مع أن المشكلة التي يتعين الخروج منها هي الأحكام

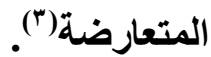

\section{سادسًا: تطبيـق القانون الأصلح للابن:}

وفقَا لهـا الاتجـاه يتعين إخضاع البنـوة الشرعية إلى القانون الأكثر صـلاحية

لمصلحة طالب ثبوت نسبه، أي الأي يؤدي تطبيقه إلى تقرير ثبوت نسبه وشرعيته، لا

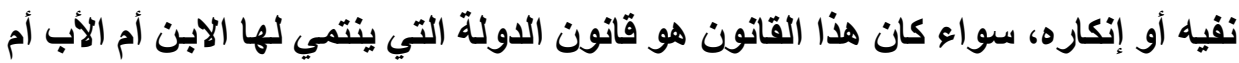
الأم أم القانون الذي يحكم آثـار الزواج("). ومـن التشريعات التي أخذت بهذأ الاتجـاه التشريع التونسي في المادة به من القانون الدولي الخاص الصادر عام 199 19.

(1)I.SUMNER \& M.VONK, National and International Surrogacy, An Odyssey, See at, https://openaccess.leidenuniv.nl/bitstream/handle/1887/29180/ISFL\%20 2011\%20-\%20Final.pdf?sequence=1, 5-7-2014.

(2)K.SAARLOOS, P.R., P.70.

(3)J.ESTER, P.R., P. 160.

(4)J.CHIANCONE and Others, Issues in Resolving Cases of International

Child Abduction by Parents, See at,
https://www.ncjrs.gov/pdffiles1/ojjdp/190105.pdf, 12-3-2014. 


\section{سابعًا: تطبيق القانون الواجب التطبيق على آثار الزواج:}

يري هذا الاتجاه أن النسب الشرعي يعد أثرًا من آثار الزواج، فيخضع لذات القانون الذي يحكم هذه الآثار. وهو ما أخذ به القانون الدولي الخاص التركي في مادته

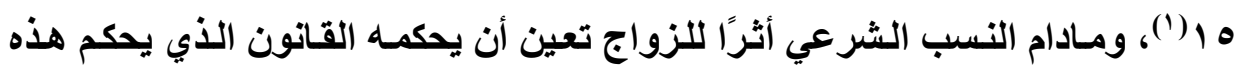

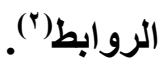
وفي ضوء ما سبق يظهر سؤال مهم مـا القانون الواجب التطبيق على النسب

الشرعي في ضوء أحكام القانون المصري؟

في ضوء غياب النص التشريعي، اختلفت الآراء حول القانون الواجب التطبيق على النسب الشرعي، فذهب الرأي الأول إلى خضوع النسب الشرعي لقـانون طالب

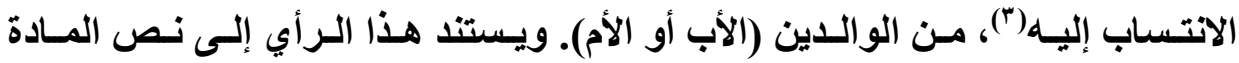

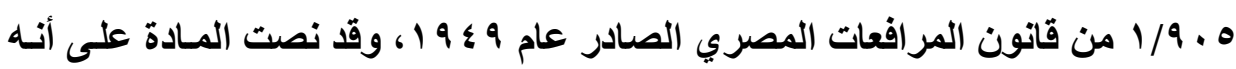
"ترفع الدعاوى بإثبات النسب وفقا للأحكام والشروط في المواعيد التي ينص عليها قانون بلا من يطلب الاتتساب إليه من الوالدين وتتبع في إثباتها القواعد التي يقررهـا القانون المذكور.

(1)A.CANYAŞ, An Analysis of Public Policy Intervention in the Recognition and Enforcement of Foreign Family Law Judgments under Turkish Private International Law, International Journal of Humanities and Social Science, Vol.2, No.17, 2012, P.7.

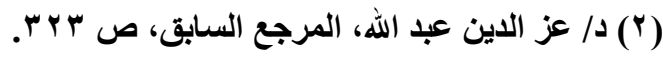

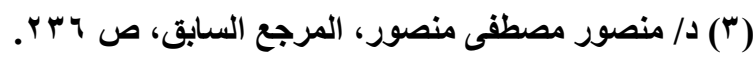


ويقدم الطلب إلى المحكمة الابتدائية التابع لها موطن المدعي".

يعني هذا أنه في حالة طلب ثبوت النسب الثرعي لولا من أبيه، فيسري قانون

دولة الأب أو يسري قانون دولة الأم إن كان المطلوب هو تقرير ثبوت النسب من الأم.

ويرى جانب آخر من الققه ـ ويحق ـ أنه يتعين تطبيق القانون الواجب التطبيق

على آثار الزواج وهو قانون دولة الأب أو الزوج، ويستند هذا الرأي للحجج الآتية('):

1- رابطة الزوجية هي البداية الحقيقية لتكوين الأسرة، ولبناء هذه الأسرة لابد من

ثبوت النسب. ويستند النسب الشرعي إلى وجود عقد زواج، ومن ثم يكون

النسب أثرًا من آثار هذا الزواج(؟)

r ـ هذا التحديد للقانون الواجب التطبيق على النسب الشرعي، يتفق مـع النظرة الشرقية لرب الأسرة المتمثل في الأب. ومن ثم لا يمكن الاستناد إلى قانون الأم

أو قانون الابن المراد ثبوت نسبه. فالبنوة الشرعية تمس مصلحة الأسرة التي تخضع لحماية الأب، فالأمر لا يتعلق فقط بمصلحة الأم أو الابن.

rـ تطبيق قانون دولة الأب يضمن وحده القانون الواجب التطبيق على النسب

$$
\text { الشرعي لكافة الأبناء داخل الأسرة الواحدة. }
$$

عـ يتفق هذا الرأي مع المادة اس من المشروع التمهيدي للقانون المدني. وهو ما يؤكد اتجـاه المشرع المصري إلى تطبيق القـانون الواجب التطبيق على آثـار الزواج وهو قانون جنسية الزوج.

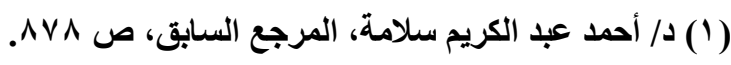

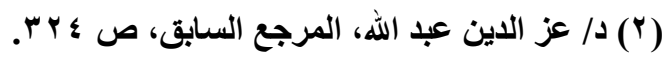


ولابد من التأكيد هنا أنتا بإقرارنا للقانون الواجب التطبيق على آثار الزواج على

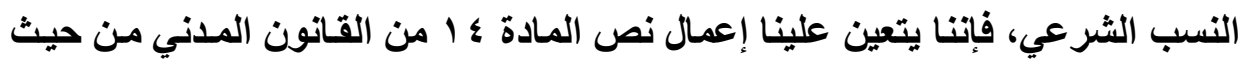
تطبيق القانون المصري إذا كان أحد الزوجين مصريًا وقت انعقاد الزواج. و إذا كان هذا هو الحال في إثبات النسب الثرعي، فما هو الوضع في النسب الغير شرعي؟ وهو الأمر الذي نجيب عليه في الصفحات التالية.

\section{المطاب الثاني}

\section{القانون الواجب التطبيق على النسب غير الشرعي}

يُقصد به الابن الناتج من علاقة غير شرعية بين رجل وامرأة، وهنـا لابد وأن

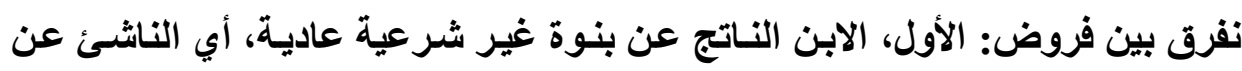

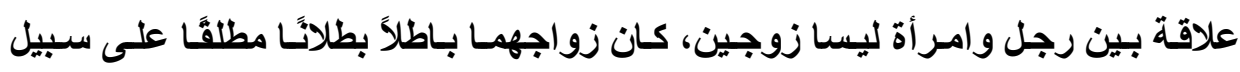

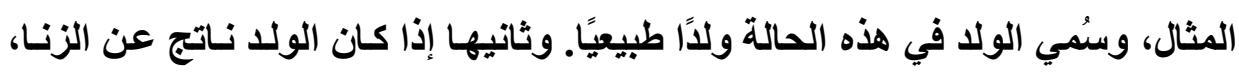

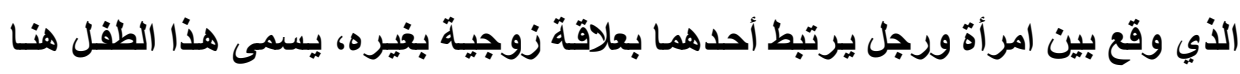

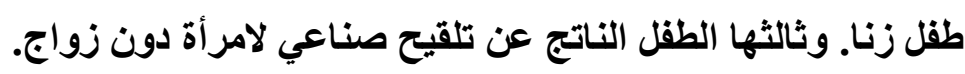
ولا تفرق الشريعة الإسلامية الغراء بين طفل الزنا والطفل الطبيعي، فكلاهمـا

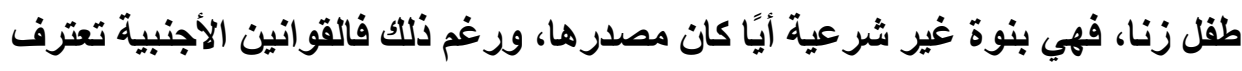

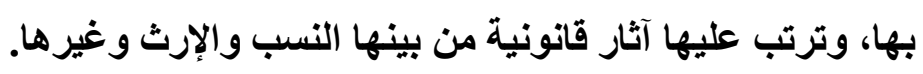
ولابد وأن نوضح هنا أن بيان القانون الواجب التطبيق قاصر على العلاقات التي

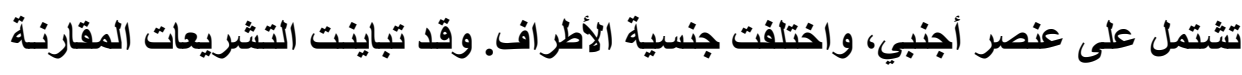
حول تحديد القانون الواجب على النسب غير الثرعي، فمن بينها مـا أقرت بتطبيق 
قانون مـن يراد الانتساب إليـه، بينمـا ذهب جانب آخر إلى تطبيق قانون الولد طالب الانتساب، ورأى قانون آخر إلى تطبيق القانون الأصلح للولا (الابن). أولاً: تطبيتق قانون الهولد (الابن): ذهب هذا الرأي إلى ترجيح تطبيق القانون الشخصي للابن، واستتد هذا الرأي إلى حجج عدة من بينها، أن البغية الأساسية لتحديد القانون الواجب التطبيق هو حمايـة الولا وإثبات مدى حقه في النفقة اللازمـة لاستمرار حياتـه. كمـا أن إثبات نسبه يتعلق بتحديد مركزه وحالته القانونية، وتوفير الحماية القانونية له. بالإضافة إلى أن هذا الولد لايسه صـوبة فـي اســــالة المفاضـلة أو الاختيـار بـين القـانون الثخـصي لأي مسن

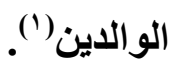

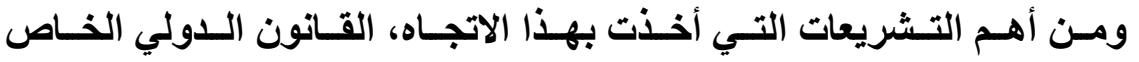

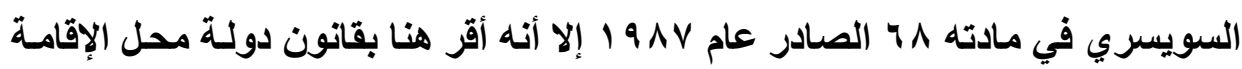
العادية للابن، بينمـا اعتبر القانون الدولي الخـاص النمساوي أن المقصود هو قانون

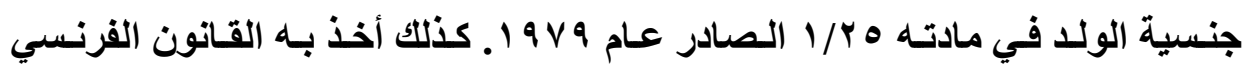
بوصفه ضابط احتياطي في حالة غياب الأم أو كونها غير مجهولة. ثانيًا: تطبيق قانون الموطن المشترك للاوالدين والولد:

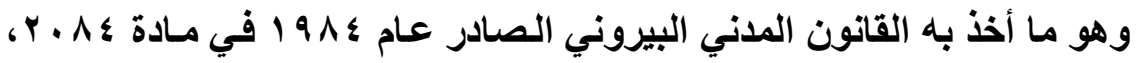
إلا أن هذا القانون يواجه صعوبة في حالة اختلاف موطنهم المشترك، وهو مـا يتصور Protection, Facultat de Dret, Universitat Pompeu Fabra, 2010, P.13. 
حدوثه عملاً. وهو ذات ما أقرته القواعد القانونية في العديد من الدول الأوربية، وكذلك برتوكول لاهاي الصادر في ץ أكتوبر الو |(') ثالثًا: تطبيق القانون الوطني للأم:

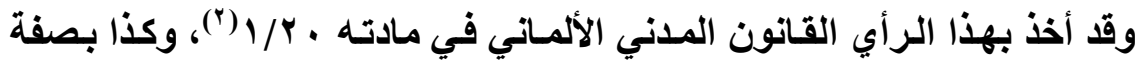
احتياطية القانون الأسباني الصادر في مادته 9/ءـ وكذلك الحال في القانون الهولندي. ويستتد هذا الر أي إلـي سـهولة إثبات نسب الصغير من أمسه، ومسن ثم التعرف علـي جنسيتها، وإلحاق نسب الصغير بها بناءً علي قانونها الوطني. والمقصود بقانون الأم الوطني هو قانون جنسيتها"(َ) رابعًا: تطبيسق القانون الأصلح للولد:

أقر هذا الاتجـاه إلى تطبيق القـانون الأكثر ملاءمـة لمصلحة الابن، ولا يحول تطبيق هذا القانون إلا تعارضه مع فكرة النظام العام. فتطبيق قانون الابن على سبيل المثال يمكن أن يؤدي إلى الإضرار بمصلحة الابن باعتباره لا يعترف سوى بـالبنوة

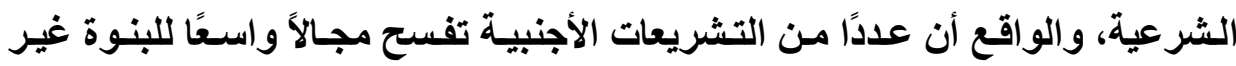
الثرعية، وهناك تشريعات لم تعد تفرق بين البنوة الثرعية والبنوة غير الشرعية كمـا في التشريع الفرنسي(؛). وهو ما أخذت به المحاكم الفرنسية في بعض أحكامها عندما

(1)A.DOUGA \& V.KOUMPLI, Cross-border maintenance obligations in Europe: the EU Maintenance Regulation, See at, http://www.hiifl.gr/wpcontent/uploads/DOUGKA.PDF, 12-3-2013.

(2)Overview of German Adoption Law, See at, http://www.adoptionpolicy.org/pdf/eu-germany.pdf, 2-6-2013.

(3)J.RIBA, P.R, P.14.

(4)BOUREL(P.) Op.Cit., P.263. 
استبعدت القـانون الجزائر ري رغم كونـهـ القانون الواجب التطبيق بوصفه قـانون الأم، استنادًا إلي أن القـانون الجزائري لا يقر بـالبنوة الغير شرعية. ومسن ثم فِإن المحكمة اتجهت إلي تطبيق القانون الأصلح للولد '(1) خامساً: قانون جنسية هن يراد الانتساب إليه: ذهب هذا الرأي - بحق ـ إلى تطبيق قانون جنسية الشخص المراد الانتساب إليه سواء أكان الأب أم الأم، ذلك أن طبيعة البنوة غير الشرعية تفترض قصر الاتتساب إلى أحد الوالدين دون الآخر من جهة، ومن جهة أخرى أن المقصود بـالبنوة الطبيعية أولاً وأخيرًا إلحاق الولا بوالده قانونًا، وهو ما يرتب آثارًا على عـاتق المنتسب إليهه، فهي تفرض عليه واجبات من أهمهار عاية الولا. بالإضافة إلى أن الأمر يمس بمركز الأسرة

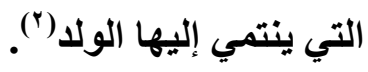
يبقى أن نبين هنا أنتا نميل إلى تطبيق قانون الأم، فإذا سلمنا سابقًا بأن القانون الواجب التطبيق على البنوة (النسب الشرعي)، هو قانون آثـار الزواج، وقد ذهبت غالبية التشريعات إلى تطبيق قانون جنسية الزوج بوصفه القانون الواجب التطبيق على آثار الزواج، إلا أنتا نرى أن نعتد بقانون جنسية الأم، فالنسبة للأم مسألة واقع،

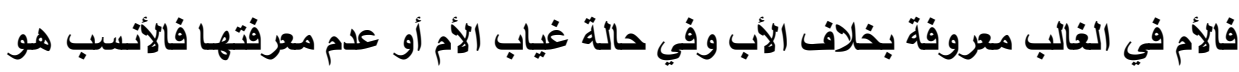
تطبيق قانون الابن، وهو الأمر الأي أخذ به القانون الفرنسي.

(1)ROQUES (L.), La politisation du droit de la nationalité, Voir à, http://www.gisti.org/spip.php?article4426, 2-12-2010.

(2)A.DOUGA \& V.KOUMPLI, Cross-border maintenance obligations in Europe: the EU Maintenance Regulation, See at, http://www.hiifl.gr/wpcontent/uploads/DOUGKA.PDF, 12-3-2013. 
ولابد وأن نؤكد هنـا أن القانون المصري قد خلي من أي قاعدة إسناد خاصـة بالنسـب غيـر الشرعي كمـا في النسب السشرعي، إلا أن القـارئ لنـصوص الأعمـال التحضيرية للقانون المدني، يجد أنها قد ألقت الاختصاص على عاتق القانون الوطني للابن، فقد نصت المادة ب ب من المشروع التمهيدي على أنه "يسري قانون الولا على المسائل الخاصة بإثبات البنوة الطبيعية وبما يترتب عليها من آثار". واستند هذا الرأي إلى اعتبارات عدة، ومن بينها أن هذه البنوة غير الشرعية تفرض الاعتبارات العملية اختصاص قانون الأم بها، وأهم جانب في هذه البنوة هو علاقة الأم بالولد الطبيعي، إلا أنه في حالة عدم وجود الأم فالأنسب هو تطبيق قانون الولا'(') ورغم هذا فإن المتأمل لنصوص قانون المرافعات الخاصـة بمسائل الإجراءات في مواد الأحوال الثخصية للاجاتب، يجد أنها نصت على اختصاص قانون من يطلب

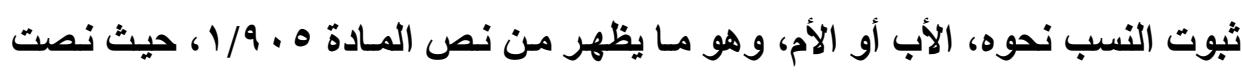
على أنه "ترفع الدعاوى بإثبات النسب وفقا للأحكام والشروط في المواعيد التي ينص عليها قانون بلا من يطلب الانتساب إليه من الوالدين وتتبع في إثباتها القواعد التي يقررها القانون المذكور". هذا النص لا يتضمن في الحقيقة قاعدة إسناد بالمعنى القني، إلا أنسه أخرج مـن اختصاص قانون القاضـي، المسائل المتعلقة بقواعد وأحكام إثبـات البنوة أو النسب، فهي من مسائل الموضوع وليس من مسائل الإجراءات، ومن ثم لا تخضع لقانون القاضي، بل تخضع للقانون الذي يحكم موضوع النزاع. ولهذا إذا كـان الأمر يتعلق بثبوت البنوة الطبيعية من جهة الأم، فيكون القـانون الواجب التطبيق هو 
قانون الدولة التي تنتمي إليها الأم، وإذا كان المراد ثبوت تلكك البنوة من جهة الأب، فيكون القانون المختص هو قانون دولة الأب(') وإذا كان الحال هكذا فيمـا يتعلق بالقانون الواجب التطبيق على ثبوت وإثبات

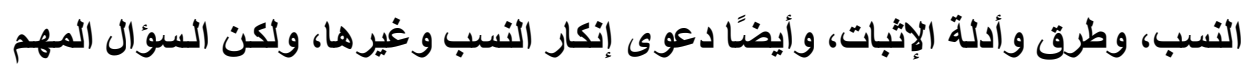
ما هو القانون الواجب التطبيق على آثار النسب؟ نرى أنه من الأفضل تطبيق القانون الواجب التطبيق على آثار النسب والنسب

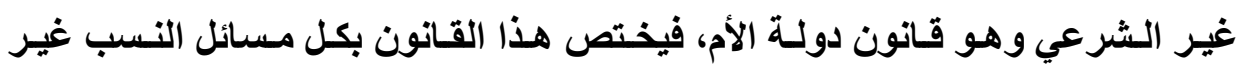

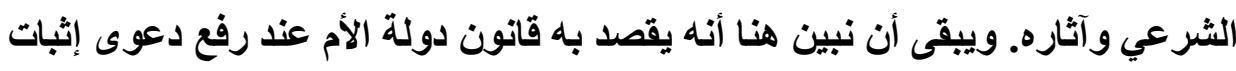

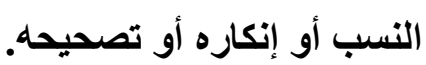
ورغم هذا يتعين علينـا أن نبين هنـا أن النسب غير الشرعي نظام لا يعرفهـ

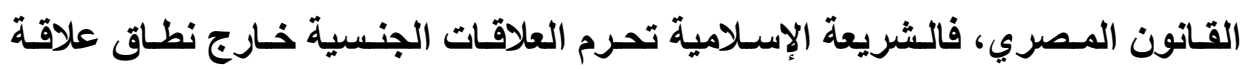

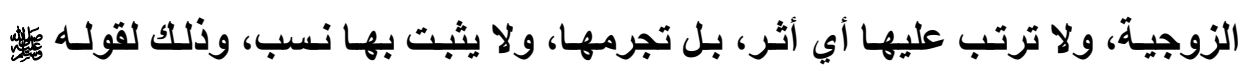

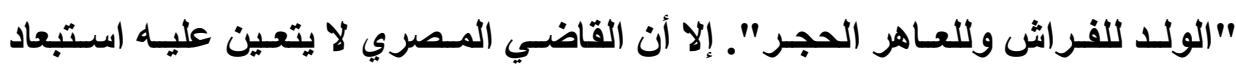
القانون الأجنبي إلا إذا ترتب على تطبيقه مساس بحقوق الوالداين والأبناء المسلمين.

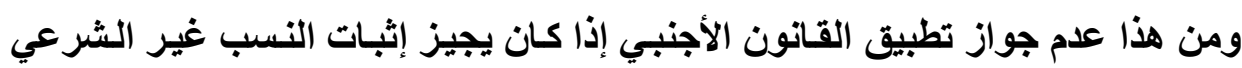

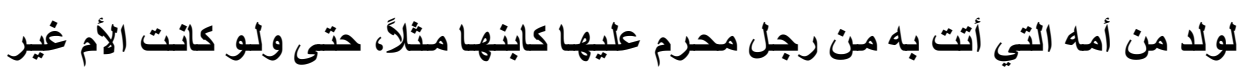
مسلمة، وكنلك استبعاده في حالة جواز إثبات النسب غير الثرعي بين المسلمين. ولكن إذا كنا قد آثرنـا تطبيق القانون الواجب التطبيق على آثار الزواج على

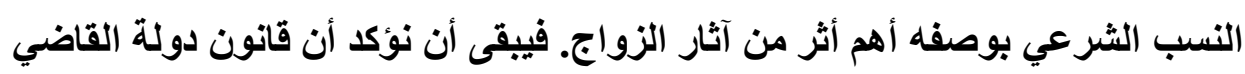


يظل حاكمًا لكافة المسائل الأخرى، ومن بينها تحديد المحكمة المختصة بدعوى النسب، وإجراءات رفعها وغيرهـا من الأمسور الإجرائية الخاصـة بسير الدعوى أمسام القضاء

ويتفق هذا مع نص المادة 7 ـ 9 من قانون المرافعات المصري التي نصت على أنه "يتبع في قبول دعوى إنكار النسب وإثباتها والمواعيد التي ترفع فيها والآثار التي تترتب عليها القواعد والأحكام التي يقررها قانون البلا الواجب التطبيق". والسؤال الآن مـا هي أهم القضايا التي يثيرهـا النسب الشرعي، وهل يقتصر الأمر على ثبوته فقط، أم أن هناك أمور أخرى لابد من البحث فيها في أثناء البحث عن بنوته؟ وما هو نطاق تطبيق القانون الواجب التطبيق علي النسب؟

\section{المطاب الثالث}

\section{نطاق تطبيق القانون الواجب التطبيق}

بينا في المطلب السابق أن القانون الواجب التطبيق وفقًا لما رجحناه هو قانون جنسية الزوج (الأب) بوصفه القانون الواجب التطبيق على آثار الزواج، وذلك وفقَا للقانون المصري. ولابد من التنويه هنا أنه في ضوء قواعد وتوجيهات الاتحاد الأوربي الصادرة عام ץ . . Y، والتي جعلت من حق طرفي عقد الزواج اختبار القانون الواجب التطبيق على الزواج وآثاره، ومن ثم سيمتد هذا القانون إلى النسب الثرعي خاصة في ظل غياب النص التشريعي في بعض التشريعات الأوروبية المقارنة(').

(1)E.RITAINE, Harmonising European Private International Law, A Replay of Hannibal's Crossing of the Alps?, International Journal of Legal Information the Official Journal of the International Association of Law Libraries, Vol.34, Issue2, 2006, P.420. 
وقد ذهب جانب من الفقه إلى قصر نطاق قانون جنسية الأب (القانون الواجب

التطبيق على آثار الزواج)، على حكم مسألة ثبوت النسب أو إنكاره أو تصحيحه('). وهو ما مال إليه جانب من الفقه الفرنسي في تفسيره للمـادة || اس/ع ا مدني، والذي ينص على أن القانون الذي يحكم ثبوت النسب (قانون الأم) لا يمتـ إلى آثار النسب، الذي يظل خاضعًا للقاعدة التقليدية، وهو القانون الذي يحكم آثار الزواج(؟). أي أن هذا الرأي يفرق بين القانون الذي يحكم إثبات النسب الشرعي والقانون الذي يحكم آثار النسب، ويتفق هذا الـرأي مـع مـا أخذت بـه المـادة ؛ ؟ مـن القـانون الـدولي الخـاص

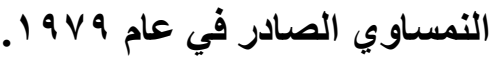

أولاً: القانون الواجب التطبيدق على تصميح النسب:

يُقصد بتصحيح النسب استخدام وسيلة قانونية بغية تصحيح نسب الولا غير

الشرعي ليصبح وللًا شرعيًا، وهو ما أقرته بعض الاتفاقيات الدولية، ومـا نصت عليه اتفاقية روما المبرمة في عام • و 19 المتعلقة بتصحيح النسب بالزواج("). كما عرفته بعض التشريعات المقارنـة المتـأثرة بالقواعد الـواردة في القـانون الكنسي، ويكـون

(1)M.PARKE, Are Married Parents Really Better for Children?, What Research Says About the Effects of Family Structure on Child WellBeing, See at, http://www.clasp.org/resources-andpublications/states/0086.pdf, 2-9-2013.

(2)H.WISE \& L.AMON, Paternity Suits Under French Law, See at, http://www.immigration-france-usa.com/gifs/pdf/paternity.pdf, 2-52014.

(3)Convention on Legitimation by Marriage, Rome Convention 1970, See at, http://ciec1.org/Conventions/Conv12Angl.pdf. 
تصحيح النسب بعدة طرق من بينها الاعتراف، الإقرار بـالبنوة، أو بـالزواج اللاحق

لحمل أو ميلاد الولا بين والايه (').

وقد اختلفت التشريعات المقارنـة في تحديـــ القـانون الواجب التطبيتق علـي

تصحيح النسب، وسوف نقصر حديثنا هنا علي القانون الواجب التطبيق علي تصحيح النسب بالزواج اللاحق.

\section{أ - تطبيقت القانون الشخصي للابن (قانون جنسية الابن).}

يذهب هذا الاتجاه إلى تطبيق القانون الشخصي للابن بوصفه أكثر اتصالاً به، ولا يثير أي مشاكل عملية في مجال تطبيقه كما هو الحسال في القانون التركي، حيث نصت عليه المادة 17 من القانون المدني التركي عليه بوصفه القانون ذا الاختصاص الاحتياطي. وكذلك نصت عليه المادة | اس/ 1 من القانون المدني الفرنسي بوصفه من

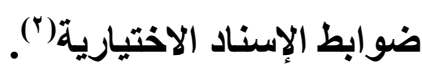

\section{ب- تطبيق القانون الأصلح للابن:}

حاول هذا الاتجـاه مراعاة مصلحة طالب الانتساب، ومن القوانين التي أخذت بهذا الاتجـاه القانون الدولي الخـاص النمساوي على سبيل الاحتياط، وكذلك القانون الدولي الخاص اليوغوسلافي (َ).

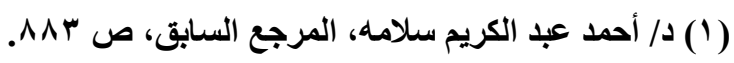
(2) M.SCOTT, P.R., P.3.

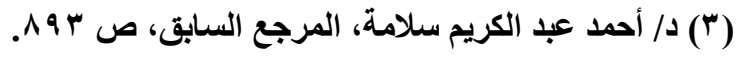
مجلتً البحوث القانونيتّ والإقتصاديت 
وفقَـا لهـذا الاتجـاه يخضع تـصحيح النسب بـالزواج اللاحق للقـانون الـوطني للوالدين. وقد أخذ بهذا الاتجـاه القـانون الدولي الخـاص النمساوي، حيث نصت المـادة r r على أنه "يحكم شروط تصحيح نسب الولا غير الشرعي بالزواج اللاحق القانون الثخصي للوالدين، وفي حالة اختلاف جنسية الوالدين، يكون القانون الواجب التطبيق هو القـانون الأكثر صـلاحية لتصحيح نسب الولــل، وقــ أخــ بهـذا الاتجـاه القـانون الفرنسي في مادته / آ/ 1 من القانون المدني على سبيل التخيير(') د- تطبيق القانون الشخصي للأب:

يذهب هذا الاتجاه إلى إخضاع تصحيح النسب بالزواج اللاحق للقانون الثخصي

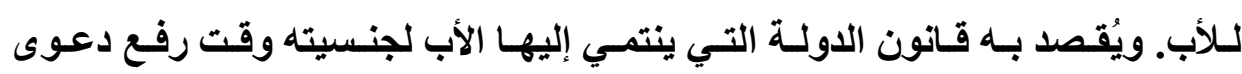
التصحيح، كما هو الحسال في المسادة 17 من القـاتون الدولي الخـاص التركي(؟). ولكن القانون الإنجليزي والأمريكي والاستر الي ذهب إلى أن المقصود بـه هو قانون دولة

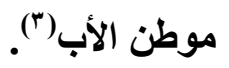

(1)H.WISE \& L.AMON, Paternity Suits Under French Law, See at, http://www.immigration-france-usa.com/gifs/pdf/paternity.pdf,2-5-2014.

(2)J.RIBA, P.R., P.15.

(3)E.RITAINE, P.R., P.422.. 


\section{هـ- تطبيق القانون الواجب التطبيق على آثار الزواج:}

ذهب هذا الاتجاه إلى إخضاع تصحيح النسب السابق على الزواج لذات القانون الواجب التطبيق على آثار الزواج، وهو مـا أخذ بـه القانون الدولي الخـاص الألمـاني

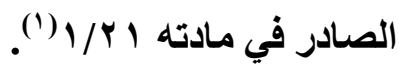

ولقد أيد جاتب من الفقه المصري هذا الاتجـاه، مستندًا إلى أن مصدر صيرورة الابن شرعيًا هو الزواج الذي تم بين والديه بعد الحمل فيه أو بعد ولادته، فـالتحول في

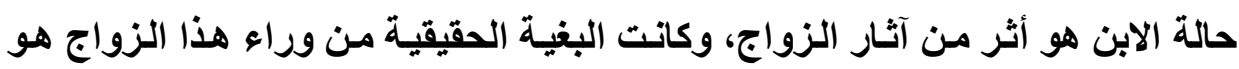
إصلاح وضع الابن ووضعه في المكان الصحيح الذي كان سيتحقى له لو أنه قد ولد في ضوء هذا الزواج. بالإضافة إلى أن تطبيق القانون الذي يحكم آثار الزواج يضمن عدم تعدد القوانين في حالة تعدد الأبنـاء المراد تصحيح نسبهم بـالزواج اللاحق لوالديهم، وهو الأمر الذي يؤكده نص المادة ه 1 من المشروع الثاني للقانون المدني المصري(). ولكن السؤال المهم مـا هو الوضـع في القانون المصري؟ هل سيقبل القاضـي المصري دعوى تصحيح نسب وقبوله لتحول صفة الولد من الابن غير الشرعي لابن شرعي؟

يمكنتا القول بأنه إذا كان طرفي العلاقة غير مصريين فلا مشكلة في هذا فيسري في خصوص تصحيح النسب بالزواج القانون الذي يحكم آثار الزواج للأسباب المبينة آنقَا. فيسري هذا القانون على الشروط الموضوعية للتصحيح بـالزواج، ومنها قيام زواج صحيح، ومنها الإقرار أو الاعتراف ببنوة الولا قبل الزواج وبعده.

(1) K.SAARLOOS, P.R., P.25.

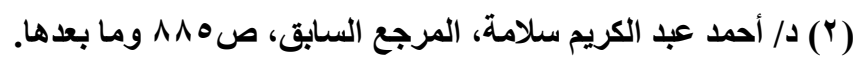

مجلتً البحوث القانونيتّ والإقتصاديتة 
ولكن إذا كان أحد أطراف العلاقة مصري فهنا تبزغ فكرة النظام العام فهذا الطقل نتـاج علاقة آثــة، ومـن ثم مـا بنـي على باطل يبقى بـاطلاً، ولا يجوز نسبته لأبويـه لتعارض هذا مع أحكام الثريعة الإسلامية. ثانيًا: القانون الواجب التطبيق على آثار النسب: يختص القانون الواجب التطبيق على آثار الزواج على ثبوت النسب، ولكن السؤال هل يمتد هذا القانون ليحكم كذلك آثار النسب؟

يعد مـن أهم هذه الآثـار فكرة الولايـة على الصغير، وغيرهـا مـن الحقوق والواجبات المتبادلة في نطاق الأسرة و الناتجة من إثبات نسب الولا لأبويه. و هذه الآثار

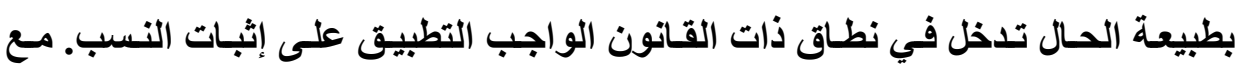
مراعاة خروج غيرها من الآثار التي أورد لها المشرع نصوصنًا خاصة في نطاق قواعد العد تنازع القوانين، ومنها على سبيل المثال لا الحصر حضانة الصغير، والنفقة والإرث

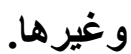

من العرض السابق نجد أنتا قد أثرنا تطبيق القانون الواجب التطبيق على آثار الزواج على النسب الشرعي، وهو في غالبية التشريعات قانون جنسية الزوج (الأب)، ولكن السؤال حول الوقت الذي يتعين فيه الاعتداد بجنسية الأب، وهنـا يتعين التفرقة

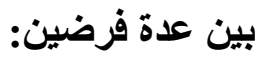
الفـرض الأول: لا تثار مشكلة إذا لم يطرأ تغيير على جنسية الأب حتى رفع دعوى ثبوت النسب أو إنكاره أو تصحيحه. الفرض الثاني: حالة تغيير جنسية الأب، فهل يعتد بجنسيته عند الزواج أم عند رفع دعوى إثبات النسب. ونحن نري أن العبرة هي بجنسية الأب وقت إبرام 
الزواج، ونستند في هذا لنص المادة ب / 1/ من القانون المدني المصري التي بينت أن القانون الواجب التطبيق على آثار الزواج هو قانون جنسية الزوج وقت إبرام عقد

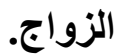

وذهب جانب آخر من الفقهاء ـ وبحق ـ إلى الاعتداد بقانون جنسية الأب وقت ميلاد الابن، ويستتد هذا الرأي إلى عدة حجج يمكن إجمالها في الآتي ('): 1ـ أن النسب من حيث الواقع يعتمد على جنسية الوالدين وقت الميلاد، وهو الأمر ذاته في حالة نقل الجنسية للأبناء.

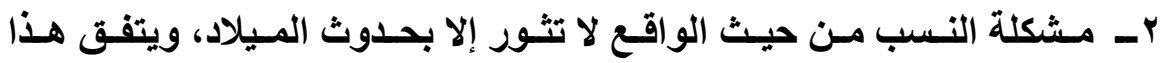

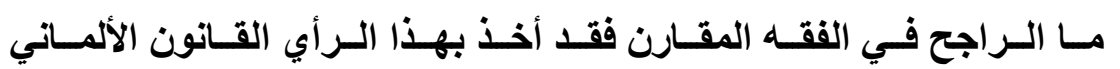

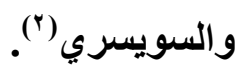

r- كمــا أنـه في حالة انفصام عرى الزوجيـة أو وفـاة الأب أثنـاء حمل الأم وقبل ميلاده، فالعبرة بقانون جنسية الأب وقت انحلال الزواج أو وقت الوفاة وهو ما أخذ بـه القانون النمساوي("). وفي حالة دعوى تصحيح النسب بـالزواج اللاحق، وحيث يسري قانون جنسية الأب، فـالعبرة بجنسية ذلك الأب وقت

$$
\text { التصحيح، أي وقت إبرام الزواج. }
$$

(2) K.SAARLOOS, P.R., P.22.

(3) K.SAARLOOS, P.R., P.282. 


\section{ثالثًا: الدنفع بالنظام العام وإثبات النسب:}

تنص المادة ^ r من القانون المدني المصري على أنها "لا يجوز تطبيق أحكام

قـانون أجنبي عينته النصوص السابقة إذا كانت هذه الأحكام مخالفة للنظـام العـام أو

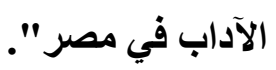

يعد النص السابق تطبيق لمبدأ استقرت عليه الأنظمـة القانونيـة المقارنـة فنجـ

$$
\text { ذات النص يلقى بظلاله على التشريعات المقارنة(') }
$$

ولقد حرصت قواعد تنازع القوانين المقارنة على اختيار القانون الأنسب لفض

المنازعات، ولهذا سمحت التشريعات المقارنة بتطبيق القوانين الأجنبية على إقليمها،

$$
\text { إلا أن هذا لا يعني أن يتم التطبيق دون قيود أو شروط(). }
$$

ويعد تطبيق النظام العام في مجال الأحوال الشخصية من أكثر المجـالات أهمية،

والنسب يعد من أهمها، فالنسب من المسائل الحساسة في هذا المجال. ولهذا تزداد أهمية النظام العام في إثبات النسب تعظم أكثر من المجالات الأخرى، لأنها رابطة لها أسس خلقيـة ودينيـة، قبل أن تكون قانونيـة. ومن ثم فـإن الطـابع الديني أو العلمـاني للنسب في قانون ما يثكل وسيلة لاستبعاد القانون المنافي لله، ويوسع من دائرة إعمال

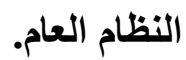

(1) R.LANGe, The European Public Order, constitutional Principles and Fundamental Rights, Erasmus Law Review, Vol.1, Issue1, 2007, P.3. (ץ) د/ هثام صـادق ود/ حفيظة الحداد، القـانون الدولي الخـاص، دار الفكر الجـامعي، الإسكندرية، 
وقد عرضنا في الصفحات القليلة القادمة للقانون المصري، وبينـا أنسه لا يعرف سوي النسب الشرعي، ومن ثم لا يعترف بالنسب غير الشرعي ونظام التبني. فمسائل

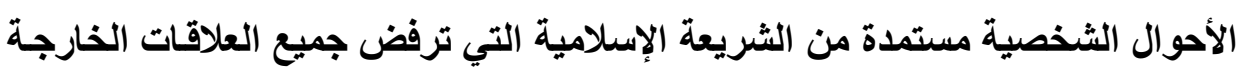
عن الإطار الثرعي، منعًا لاختلاط الأنساب والحفاظ عليه من الفساد. ومسألة النسب الطبيعي هي التي تثير أكبر الصعوبات للتنـاقض الموجود بين الدول، فمصر علي سبيل المثال دولة لها طابع ديني، ومن ثم سيرفض قضائها أي طلب باثبات نسب طفل غير شرعي، ولا عبرة هنا لكونه نتاج علاقة جنسية بين امرأة ورجل أو حتى من زواج بين مثليين (امرأتـان تم تلقيح إحداهما بمنسي رجل من أحد بنـوك الإخصاب) (') فالقاضي المصري سوف يرفض بكل قطع أي طلب لإثبات نسب ابن نتج

(1) لابد وان نوضح هنـا أن زواج المثليين أصبح لـه طابع الشرعية، فمع فرنسا أصبح زواج مثلي

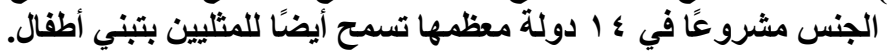

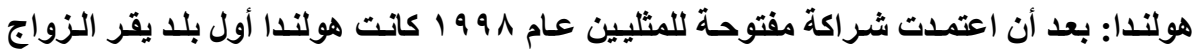

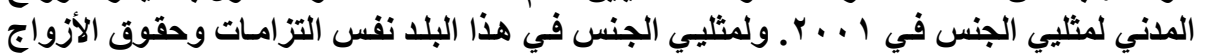
العاديين ومن بينها الحق في تبني أطفال.

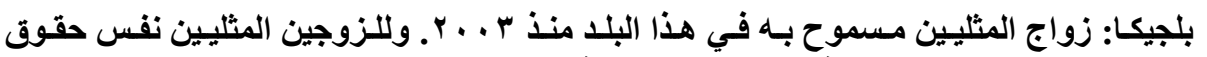

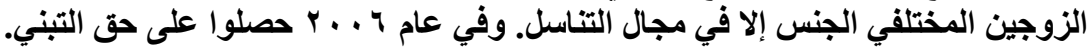

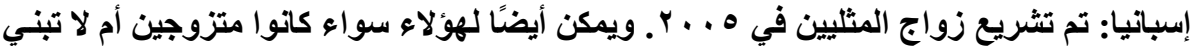

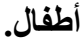
كثدا: دخل قانون زواج المثليين والتبني حيز التتفيذ في ه . . r. وكانت معظم الأقاليم الكندية تسمح بالفعل بزواج مثلي الجنس.

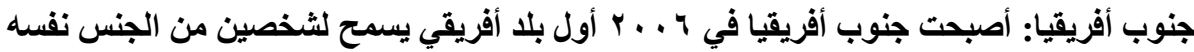

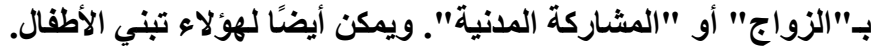

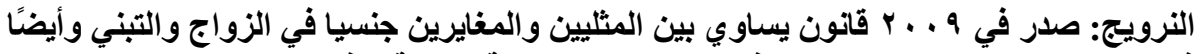

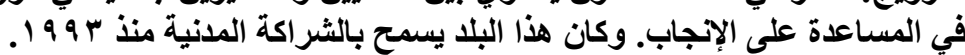

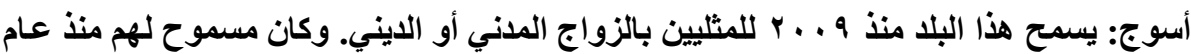

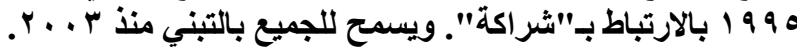

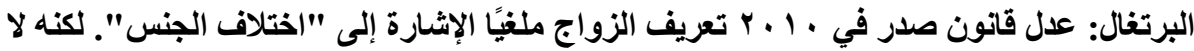
يسمح للمثليين بالتبني. = 
من علاقة جنسية خارج إطار الزواج. كما أنه سيرفض أي تطبيق لقانون يقر مثل هذه العلاقات كما هو الحال في استبعاد القانون البلجيكي الذي يقر زواج المثليين أو القانون

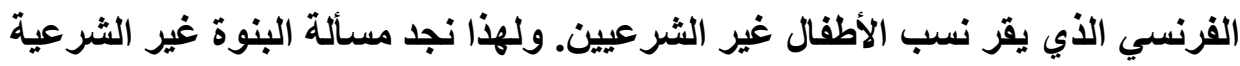
هي التي تثكل المساحة الأكبر للافع بالنظام العام في مسائل إثبات النسب. وإذا كان الحال كنلك في القوانين التي نستند لمرجية دينية كما هو الحال في

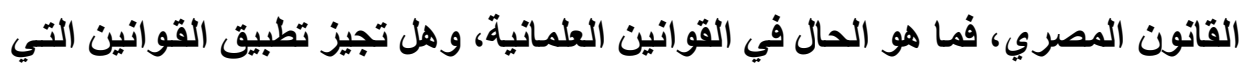

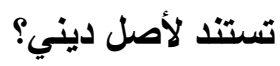

المتأمسل للوضسع في القـانون الفرنسي يجد القضاء الفرنسي استبعد تطبيق

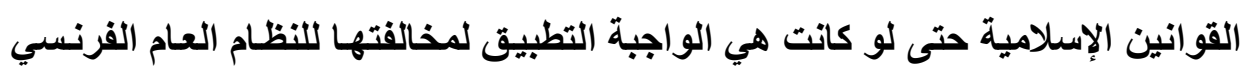

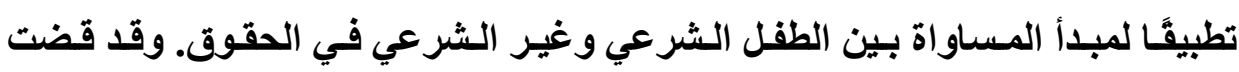

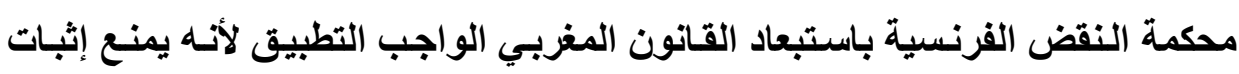

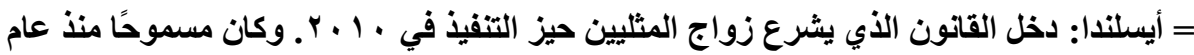

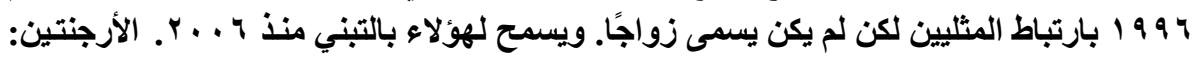

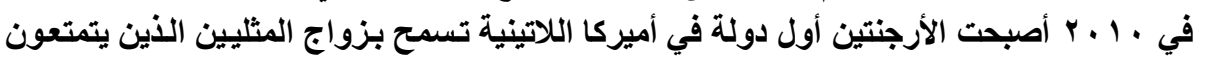
بنفس حقوق الأزواج العاديين ومنها التبني.

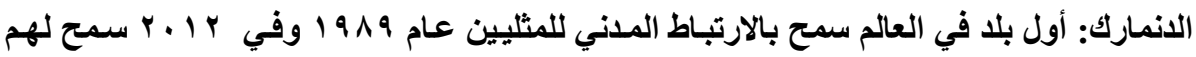
بالزواج في كنيسة الدولة اللوثرية.

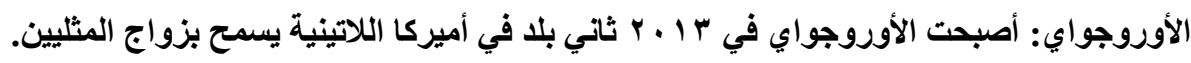

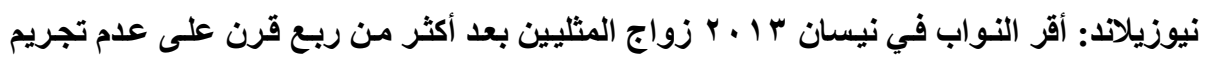

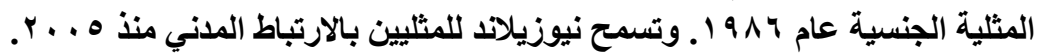

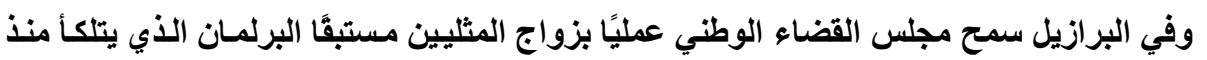

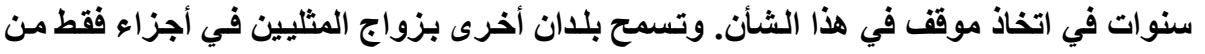
أراضيها مثل المكسيك في العاصمة الفدرالية مكسيكو والولايات المتحدة. 
النسب خـارج الزواج، وإحلال القانون الفرنسي محلـه الذي يجيز هذا الإثبات للطفل المقيم بصورة معتادة في فرنسا، والذي لله جنسية فرنسية متمتعًا بها عن طريق أمسه، وذلك كي يتمكن الطقل من إثبات نسبه تجاه والده الطبيعي. وييرر جانب من الفقه هذا

الاتجاه من القضاء الفرنسي بأنه سعي نحو حماية الطقل وإعلاء مصلحته('). إلا أن محكمة النضض الفرنسية رغم هذا ما لبث أن أكلت علي أن الدفع بالنظام العـام لاسـتبعاد القوانين الإسـلامية لـه ضـابط موضـوعي وضـابط إجرائس، فاشـترطت لاستبعاد قانون الأم المتمتعة بالجنسية الجزائرية، والذي لا يعرف نسب الطقل الشرعي أن تكون الطقلة (طالبة الانتساب) متمتعة بالجنسية الفرنسية أو مقيمة علي الأراضي الفرنسية. ومـن ثم ونتيجة لذلك رفضت المحكمة طلب الأم باستبعاد تطبيق القـانون

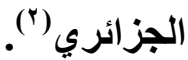
يبقى أن نؤكد في النهايـة على فكرة النظام العام، وحق القاضسي في استبعاد تطبيق القانون الأجنبي إذا وجد تعارض بينه وبين النظام العـام الداخلي، كمـا لو حرم الولا من إثبات نسبه أو إعفاء الأب من النفقة أو رعاية الأبناء.

(1)http://www.legifrance.gouv.fr/affichJuriJudi.do?idTexte=JURITEXT00 0007030229, 10-2-2012.

(2)https://www.courdecassation.fr/formation_br_4/2006_55/penale_2006_8 476.html, 13-4-2012. 


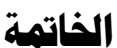

عرضنا في خلال دراستنا للقانون الواجب التطبيق علي إثبات النسب من خلال

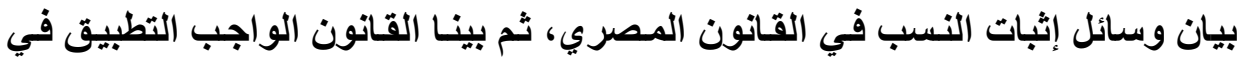

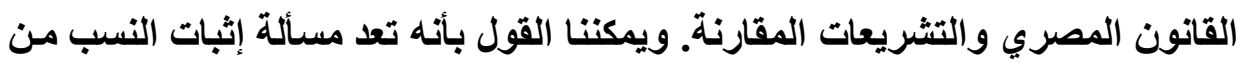
المسائل الثائكة علي الصعيدين الوطني والدولي. و المتأمل لقواعد النسب في القانون المصري يجد أنه لم يعرف إلا إثبات النسب

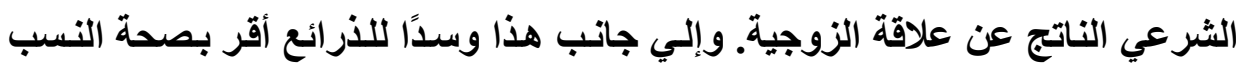
الناشئ عن زواج فاسد أو وطء بثبهة. كما أقر بإمكانية إثبات النسب من خلال وسيائل

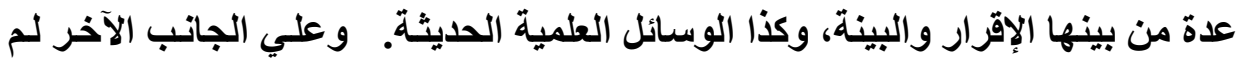
يعرف القانون المصري إثبات النسب بالنسبة للطفل غير الثرعي. و وعلي صعيد قواعد تنازع القوانين خلي القانون المصري من أي قاعدة إسناد خاصة بالقانون الواجب التطبيق علي إثبات النسب، وفي ضوء واتئ غياب النص التشريعي

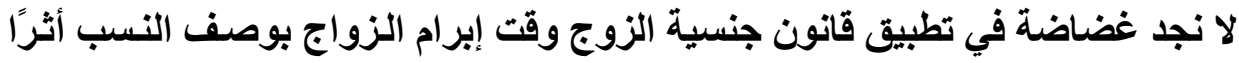

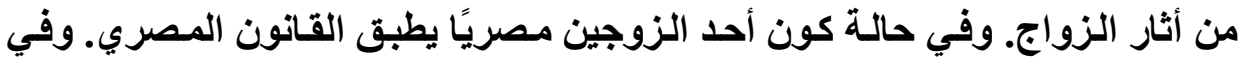

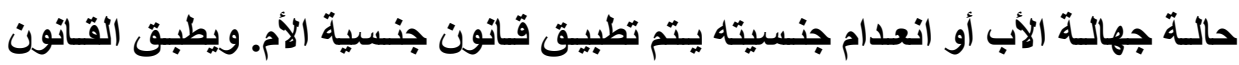
المصري في حالة اللقيط المولود علي الأراضي المصرية.

كما بينا في النهاية الدور المهم للافع بالنظام العام في القانون المصري في استبعاد القانون الأجنبي في حالة مخالفته للأسس القانونية والاينية والأخلاقية لقانون

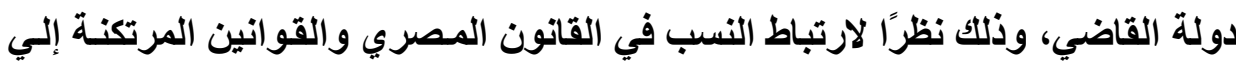
أسس دينية كما في البلان الإسلامية لقواعد الثريعة الإسلامية التي تحظر إثبات نسب الثبان 


\section{قائمة المراجع}

\section{أولاً: المراجع القانونية:}

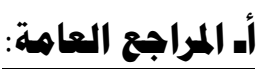

1. د أحمد عبد الكريم سـلامة، أصول المرافعات المدنيـة الدولية، مكتبة العالميـة،

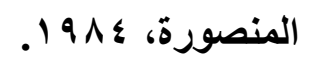

r. د د/ أحمد عبد الكريم سلامة، علم قاعدة التنازع والاختيار بين الشرائع، أصولاً ومنهجًا، مكتبة الجلاء الجديدة، المنصورة، الطبعة الأولى.

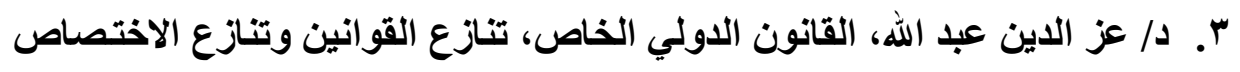

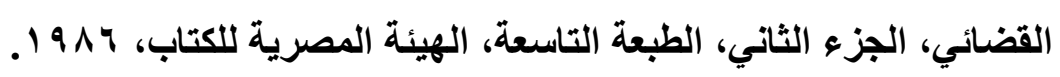
؛. د د/ هشام صادق ود/ حفيظة الحداد، القانون الدولي الخـاص، دار الفكر الجامعي،

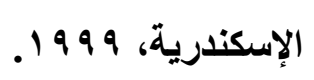

\section{ب ـ المراجع المتخصصة:}

•. د د/ إبراهيم عبد الرحمن إبراهيم، الوسيط في شرح قانون الأحوال الثخصية، دار

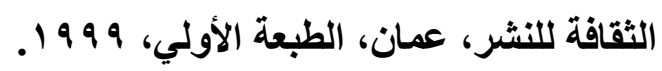
\. د د/ أحمد أحمد، النسب في الشريعة والقانون، دار العلوم، الكويت، الطبعة الأولى، .1914 V. د د/ أحمد نصر الجندي، محكمة الأسرة واختصاصها، دار الكتب القانونية، ه . . Y. 
^. ـ د/ أحمـد نـصر الـدين الجنـدي، النسبب في الإسـلام والأرحسام البديلـة، دار الكتب

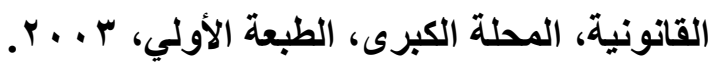

9. د/ حـافظ محمـود، دور البـمة الوراثيـة فـي تحديــ النسب، دار القبـة للنشر

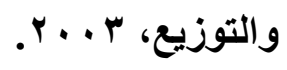

• 1 .د/ حسن حسن منصور، المحيط في مسائل الأحوال الشخصية، أحكام عقد الزواج بين الآراء الفقهية وأحكام القضاء، المؤسسة الوطنية للطباعة والنشر والتوزيع،

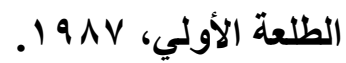

11 ا.د/رمضان علي الشرنباصى، أحكام الأسرة في الشريعة والقانون، دار الجامعة

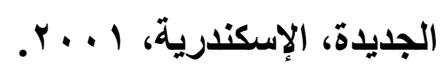

r ا ـد/ محمد أبوزهرة، الأحوال الشخصية، دار الفكر العربي، 199 1. ب 1 ـد/ محمد محي الدين عبد الحميد، الأحوال الثخصية في الشريعة الإسـلامية،

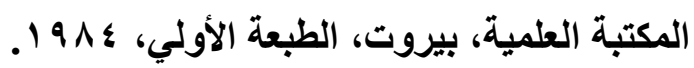

ـ ا.د/ معوض عبد التواب، موسوعة الأحوال الثخصية حسب آخر التعديلات، الجزء الأول، دار الوفاء، المنصورة، الطبعة الخامسة، ، 99 19. ه ادد/ وهبة الزحيلي: الفقـه الإسـلامي وأدلته، دار الفكر، دمشثق، الطبعـة الرابعة، .11 1 ا.موسـوعة الأحسوال الثخصية حسب آخـر التعـديلات، الجـزء الأول، دار الوفــاء، المنصورة، الطبعة الخامسة، . 99 19. 


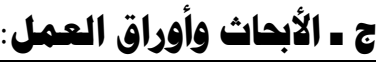

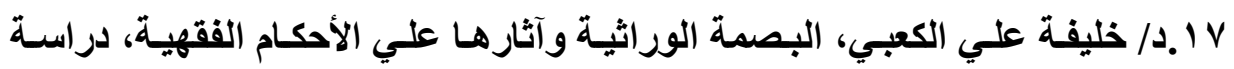

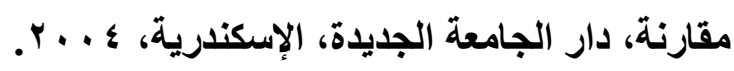

1 1.د/ عبد العزيز مخيمر، اتفاقية حقوق الطفل خطوة للأمسام أم إلى الوراء، مجلة البحوث القانونية والاقتصادية، كلية الحقوق- جامعة المنصورة، العدد، بـو 19. 9 1.د/ منصور حسن منصور، الولا للفراش والبصمة الوراثية، مجلة الأزهر، الجزء

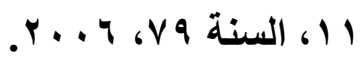

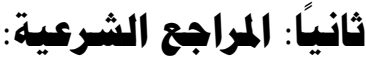

•†.أبو إسحاق إبراهيم بن علي بن يوسف الثيرازي، المهذب، الجزء الثالث، دار الكتب العلمية، بدون سنة نشر.

اب.أبو بكر بن العربـي المـالكي، أحكام القرآن، الجزء الثالث، دار الكتب العلميـة، r...r ץ ץ.أبو زكريا محيي الدين يحيى بن شرف النووي، روضة الطالبين، الجزء السادس،

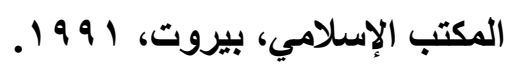

بr .كمال الدين بن عبد الواحد، شرح فتح القدير، الجزء الثالث، دار الفكر، بدون سنة نشر. צ ؟.محمد بن أبي بكر بن أيوب ابن قيم الجوزية، زاد المعاد في هدي خير العباد،

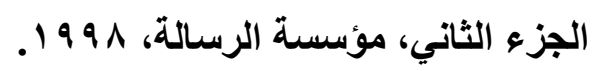


ه r.محد بن عبد الباقي بن يوسف الزرقاني المصري الأزهري، شرح الزرقاني على موطأ الإمام مالك،، مكتبة الثقافة الدينية، الجزء الثالث، القـاهرة، الطبعة الأولي، r...r

\section{ثالثًا: المراجع اللغوية: - اجية}

צY.أحمد بن فارس بن زكريـا أبو الحسين، معجم مقاييس اللفة، الجزء الرابع، دار

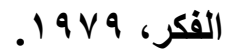

rV Vحمد بـن مكرم بـن منظور الافريقـي المصري جمـال الـدين أبو الفضل، لسان

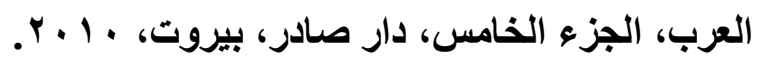
؟Y.لسان العرب، دار صادر، بيروت، الطبعة الرابعة، ؛ 99 1. رابهًا: المراجع الأجنبية: أ ـ المراجع الإنجايـزية:

\section{General References:}

29.J.ESTER, Illegitimate Children and Conflict of Laws, Indiana Law Journal, Vol.36, Issue 2, 1961.

30.J.RIBA, Principles and Prospects for a European System of Child Protection, Facultat de Dret, Universitat Pompeu Fabra, 2010. 


\section{Articles and Researches:}

31. A.CANYAŞ, An Analysis of Public Policy Intervention in the Recognition and Enforcement of Foreign Family Law Judgments under Turkish Private International Law, International Journal of Humanities and Social Science, Vol.2, No.17, 2012.

32. E.RITAINE, Harmonising European Private International Law, A Replay of Hannibal's Crossing of the Alps?, International Journal of Legal Information the Official Journal of the International Association of Law Libraries, Vol.34, Issue2, 2006.

33. K.SAARLOOS, European Private International Law on Legal Parentage, Thoughts on a European Instrument Implementing, The Principle Of Mutual Recognition in Legal Parentage, Degree of Doctor, Maastricht University, 2010.

34. P.MOZOS, Recognition in Spain of Parentage Created by Surrogate Motherhood, Yearbook of Private International Law, Vol.12, 2010. 
35. R.LANGE, The European Public Order, constitutional Principles and Fundamental Rights, Erasmus Law Review, Vol.1, Issue1, 2007.

\section{Articles on Internet:}

36.A.DOUGA \& V.KOUMPLI, Cross-border maintenance obligations in Europe: the EU Maintenance Regulation, See at, http://www.hiifl.gr/wp-content/uploads/DOUGKA.PDF.

37.A.DOUGA \& V.KOUMPLI, Cross-border maintenance obligations in Europe: the EU Maintenance Regulation, See at, http://www.hiifl.gr/wp-content/uploads/DOUGKA.PDF.

38. C.SUMNER, Private International Law Aspects of Homosexual Couples: The Netherlands Report, See at, http://www.ejcl.org/111/art111-8.pdf.

39.F.PESCE, Diversity in a United World of Child Support, Country reports, Italy, See at, http://www.heidelbergconference2013.de/tl_files/downloads-abstracts/abstractsab-3-3-2013/Abstract_PESCE.pdf.

40.H.WISE \& L.AMON, Paternity Suits under French Law, See at, http://www.immigration-franceusa.com/gifs/pdf/paternity.pdf. 
در رشا على الدين أحمد

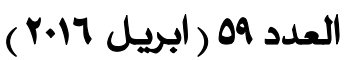

41.I.SUMNER \& M.VONK, National and International Surrogacy, An Odyssey, See at, https://openaccess.leidenuniv.nl/bitstream/handle/1887/2918 0/ISFL\%202011\%20-\%20Final.pdf?sequence $=1$.

42.J.CHIANCONE and Others, Issues in Resolving Cases of International Child Abduction by Parents, See at, https:/www.ncjrs.gov/pdffiles1/ojjdp/190105.pdf.

43. L.HARRIS, The Basis for Legal Parentage and The Clash between Custody and Child Support, See at, https://mckinneylaw.iu.edu/ilr/pdf/vol42p611.pdf.

44. L.SILBERMAN, The Hague Convention on Child Abduction and Unilateral Relocations by Custodial Parents, A Perspective from the United States and Europe - Abbott, Neulinger, Zarraga, See at, https://www.law.ou.edu/sites/default/files/files/OU_LAW_A DMIN/07\%

45. M.PARKE, Are Married Parents Really Better for Children?, What Research Says About the Effects of Family Structure on Child Well-Being, See at, http://www.clasp.org/resources-andpublications/states/0086.pdf, 2-9-2013. 


\section{ب ب المراجع الفرنسية:}

46. BOUREL(P.) et les autres, Droit International Privé, Dalloz, Paris, 10e édition, 2013.

47. ROQUES (L.), La politisation du droit de la nationalité, Voir à, http://www.gisti.org/spip.php?article4426.

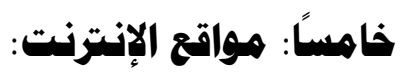

48. http://www.adoptionpolicy.org/pdf/eu-germany.pdf.

49. http://www.alukah.net/sharia/0/40912, 12-10-2014.

50.http://www.cc.gov.eg/Courts/Cassation_Court/Civil/Cassati on_Court_Civil.aspx.

51.http://www.cc.gov.eg/Images/Madany/2006/2/585-73/58573.pdf

52. http://www.hse.ru/data/2012/06/08/1252692468/SwissPIL\% 20 в\%20ред.\%202007\%20\%28англ.\%29.pdf

53.www.dar-alifta.gov.eg. 